Article

\title{
Selection of the Most Sustainable Renewable Energy System for Bozcaada Island: Wind vs. Photovoltaic
}

\author{
Elif Oğuz ${ }^{1, * \mathbb{D}}$ and Ayşe Eylül Şentürk ${ }^{2}$ \\ 1 METUWIND, Hydromechanics Laboratory, Civil Engineering Department, \\ Middle East Technical University, 06800 Ankara, Turkey \\ 2 Hydromechanics Laboratory, Civil Engineering Department, Middle East Technical University, \\ 06800 Ankara, Turkey \\ * Correspondence: elifoguz@metu.edu.tr
}

Received: 24 June 2019; Accepted: 23 July 2019; Published: 29 July 2019

\begin{abstract}
Energy production without destroying the environment has been one of the most crucial issues for people living in today's world. In order to analyze whole environmental and/or economic impacts of the energy production process, life cycle assessment (LCA) and life cycle cost (LCC) are widely used. In this study, two distinct renewable energy systems are assessed. First, a land-based wind farm, which has been operating in Bozcaada Island since 2000, is compared to a proposed solar photovoltaic power plant in terms of Energy Pay-Back Time (EPBT) periods and greenhouse gas (GHG) emissions and life cycle cost. The energy production process including the recycling phase evaluated "from cradle to grave" using GaBi software for both cases. All scenarios are compared by considering different impact categories such as global warming potential (GWP), acidification potential (AP), and eutrophication potential (EP). Following this, levelized unit cost to produce $1 \mathrm{MWh}$ electricity (LUCE) is calculated for both systems. This study revealed that LCA and LCCA are useful and practical tools that help to determine drawbacks and benefits of different renewable energy systems considering their long-term environmental and economic impacts. Our findings show that onshore wind farms have a number of benefits than proposed photovoltaic power plants in terms of environmental and cost aspects.
\end{abstract}

Keywords: LCA; LCC; photovoltaic; onshore wind; renewable energy

\section{Introduction}

Climate change is one of the most critical issues for the future of the world. One of the major reasons for climate change is greenhouse gas (GHG) emissions. Therefore, reduction in greenhouse gas emissions is recognized as an important step [1] to avoid the devastating effects of climate change. As the focus on reduction in GHGs increases, researchers are seeking ways to mitigate climate change by applying environmentally-friendly solutions such as green technologies, hybrid systems, and renewable energy systems. In this context, a significant amount of research and development activities have been carried out to determine feasible renewable energy systems for a wide range of engineering fields. The International Maritime Organization (IMO) introduced a number of regulations such as maritime pollution (MARPOL) Annex VI (2014). According to MARPOL Annex VI, oil companies and engine manufacturers have to follow stringent rules and guidelines in order to decrease SOx and NOx emissions [2]. Since the regulatory legislation for ship emissions in the maritime industry has brought the need for improving energy efficiency for environmental benefits, organizations, and governments that started to give funds for research and development studies in this field. Recently, three HORIZON2020 Projects (namely Ship Life cycle software solutions (SHIPLYS, HOLISHIP and LINCOLN) are funded by the European Union (EU) [3], which aims to 
develop the software integration process for ships considering environmental benefits and their outcomes published in References [4-9]. Integration of renewable energy technologies to short-route ferries [10] are also carried out in order to emphasize the importance of such systems in reducing the emissions for the countries that currently have no stringent regulation. Similarly, renewable energy sources (RES) are suggested by a number of researchers [11-15] to reduce air pollution and climate change instead of traditional energy production systems where fossil fuels utilize. The integration of renewable systems with the idea of local co-production is considered an excellent way for mitigating climate change [16]. In recent years, sustainable building with the idea of local co-production has been investigated all around the world [17-19] in order to follow International Partnership for Energy Efficiency Cooperation (IPEEC) regulations [20] for zero energy building with the aim to decrease in emissions. After successful applications in the construction sector, some governments started to give funds for the integration of renewables for larger-scale construction areas, namely, new cities. In the 21st century, smart city concepts have been developing to integrate renewable technologies [21] into the production of self-electricity requirements of the new cities. One of the main reasons of enormous greenhouse gas emissions are considered as the emissions from the maritime application as well as the self-electricity need of an island, known as hydrogen islands [22], can be one of the solutions for decarbonizing maritime transportation by means of hydrogen refueling stations. In this study, Bozcaada Island is chosen not only to be the potential of a smart city but also to be the first hydrogen island of Turkey, according to the United Nations Industrial Development Organization (UNIDO) project [23]. Bozcaada island has significant solar energy potential, $308.0 \mathrm{cal} / \mathrm{cm}^{2}$ sunshine radiation per day, and $7.5 \mathrm{~h}$ sunshine duration per day, as well as wind energy potential with $8.4 \mathrm{~m} / \mathrm{s}$ average wind speed at $50 \mathrm{~m}$ [24]. Although there is an operating wind farm in Bozcaada island, investigation of the photovoltaic power plant should be carried out due to solar energy potential in this region. Two different configurations, namely, existing wind farm and proposed photovoltaic (PV) plant, are compared in terms of environmental and economic aspects by using life cycle assessment (LCA) and life cycle cost analysis (LCCA). Both previously mentioned renewable energy technologies are evaluated in terms of "cradle to grave perspective". The production processes of raw materials are included throughout the analysis even though transportation of raw materials such as silica in the LCA of the PV system and steel in the LCA of onshore wind farm are excluded.

The introduction starts with research motivation of the study and a review of LCA applications in various industries to determine the applicability of the method. Following this, limited application of solar energy and LCA of the renewable energy systems are summarized. The model structures and assumptions related with renewable energy technologies and lifecycle inventory analyses are presented in Sections 3 and 4. A sensitivity analysis is carried out for both systems in order to determine the most feasible recycling strategy, which is presented in Section 5.3. However, the end of life approach is considered only as a suggestion in the case of a PV system due to the fact that there is still no strict way to recycle the procedure of photovoltaic technology. Both technologies are modelled and evaluated using GaBi software. Following the evaluation of environmental impacts, life cycle cost analyses are carried out with both renewable systems. LCA and LCCA results are presented in Section 5. Lastly, discussions are made in Section 6 and future directions are mentioned in Section 7.

\subsection{Research Motivation}

One of the key objectives of this study is carrying out LCA and LCCA of the photovoltaic power plant since there is no specific study published in Turkey. In this study, photovoltaic power is evaluated for the first time in terms of environmental impacts in Turkey.

\subsubsection{Review of Life Cycle Assessment (LCA) and Life Cycle Cost (LCC)}

LCA methodology can be defined as an evaluation procedure of a product, a process, or a system in terms of environmental characteristics with a "cradle to grave perspective." By means of this method, the systems, containing extraction or acquisition of raw materials and manufacturing, 
transportation of raw materials, and construction procedures starting with infrastructure and finishing with the installation of design structure, use process and reuse, recycling, or disposal of waste materials that can be evaluated for an entire life. LCA methodology has a widespread utilization area around the world. For example, LCA in the infrastructure structure [25] is applied for capturing all changes due to the decisions instead of utilization of embodied carbon calculator tools in order to manage emissions of infrastructure projects. As another example from the infrastructure sector, the requirement of integration of disassembly and deconstruction phase into building information systems [26] are shown by means of LCA methodology. Apart from infrastructure, Australian read meat supply chains focusing on Australian beef and lamb exported to USA [27] is evaluated in terms of environmental impacts with the application of LCA. In the case of the energy sector, Atilgan and Azapagic [28] state that the expansion of renewable technologies is essential for Turkey's electricity from the medium to long term and Atilgan and Azapagic [29] focus not on the sun but on renewable electricity generated with the utilization of hydro, wind, and geothermal sources in Turkey. As another example of the energy sector, the electricity mix of French territories are studied with the cradle-gate electricity production model and Guyana is reported as the lowest GHG emissions than other islands by Rakotoson and Praene [30].

As an economic evaluation procedure, the life cycle cost analysis, which aimed to predict the total cost of a system, a product, or a process throughout the lifespan, is becoming popular around the world. For instance, the analysis of life cycle cost is carried out by Utne [31] for Norwegian fishing fleet whether LCC can be used as a tool to improve sustainability. In automotive manufacturing, the life cycle cost analysis is conducted [32] for a distinct type of composite materials in order to select an appropriate one for the design of a lightweight automotive. Jeong et al. [9] tried to draw a framework for selecting an optimal propulsion system by combining the life cycle and cost assessment for the shipping industry. Life cycle cost analysis of a defense electronic system [33] is utilized to be able to determine end-of-life cost during the early design step. LCA and LCC for the electricity mix of Turkey are carried out as a first time by Yllan [34]. She selected a levelized cost of electricity as an indicator for the future electricity mix.

The leading software products, which are GaBi and SimaPro, are utilized in the market more than 20 years [35] as life cycle assessments tool. Although there are few studies related with the compassion of LCA software tools, the comparison between GaBi and SimaPro was conducted for the packaging system [36] and continued with simplified systems [37] for the creation and disposal of four basic materials, which are aluminum, polyethylene terephthalate, glass, and corrugated board. All of these are 1 kilogram. Despite the fact that the comparison of the simplified systems concluded that the differences of impact analysis, which is greater than $20 \%$, are caused by the differences in the characterization factors used by the two programs, it is reported that [38] there is no difference between using SimaPro and GaBi for ordinary and even skilled LCA software users in terms of the capability to detect potential errors. GaBi software is presented as the best one [39] in terms of user-friendliness, service, and functionality whereas the best specification for SimaPro is determined to be the cost. Due to a user-friendly specification, $\mathrm{GaBi}$ is utilized for the modelling and evaluation procedure of this study.

\subsubsection{LCA Applications of Renewable Technologies}

Since two distinct renewable systems to generate electricity in Bozcaada Island are investigated in this study. Previous LCA studies of solar panels and onshore wind farm applications are presented in the following.

\section{LCA of Solar Panels}

Application of life cycle assessments methodology for the open ground mounting is very rare in the literature since the grid connection of photovoltaic technology and its application is relatively newer than the grid connection of wind power. For example, the installation of photovoltaic power 
plant composed of multi-Si solar panels is recommended Fu et al. [40] without taking into account therecycling phase of plants even though multi-Si production leads the highest contribution to environmental impacts. Although there are a lot of LCA studies in the literature, they differ from each other by either one aspect or more since there are a lot of classifications of photovoltaic electricity. Classification type of photovoltaic technology can be summarized as the type selection of solar modules and installation styles of solar panels basically. Solar cells produced a multi-Si wafer has the most widespread application than other type of solar cells, including mono-crystalline, thin-film layer, CdTe, and CIS. In the case of installation styles, ground mount installation, namely land-based application, and roof-top installation, which can be categorized as slanted-roof and flat-roof installation, can be regarded. In addition to this, photovoltaic systems are divided into two basic groups as stand-alone (independent, off-grid) PV systems and network connected (grid-connected, on-grid, grid-tied) systems. In order to make a meaningful classification, LCA studies about photovoltaic electricity especially based on crystalline-cell type tabulated in Table 1 by noting the results of energy pay-back time and GHGs. In Table 1, the first row of phases shows the onset of the life cycle analysis as the second row demonstrates end phases of the research studies listed.

Since LCA of PV systems considering the "cradle to grave" perspective are limited, as indicated by Nugent and Sovacool [41].

Table 1 presents publicly available studies for different locations in the world.

LCA of the Onshore Wind Farm

Applications of life cycle assessment methodology for onshore wind farm is widespread around the world as opposed to a land-based photovoltaic power plant. For example, in the European region, the climate change impacts during the life cycle and energy payback time (EPBT) of the onshore wind plant are reported as less than $7 \mathrm{~g} \mathrm{CO}_{2}$-eq./kWh and 7 years, respectively [42]. In the case of Texas [43], GHG emissions are classified for different turbine sizes. Global warming potential of $1 \mathrm{MW}$ is $7.35 \mathrm{~g} \mathrm{CO}_{2}$-eq. GWPs of $2 \mathrm{MW}$ and $2.3 \mathrm{MW}$ turbines are found as $7.09 \mathrm{~g} \mathrm{CO}_{2}$-eq. and $5.84 \mathrm{~g} \mathrm{CO}_{2}$-eq., respectively. The comparison between the model type of wind turbines is conducted [44] and EPBTs are calculated as 0.43 and 0.53 years for the selected turbine models. As a result, the LCA application of wind energy is more common than the photovoltaic system since wind power technology is older than photovoltaic technology.

\section{LCA of Photovoltaic vs. Wind Systems}

To the author's best knowledge, research on the selection of appropriate systems for the selected region is limited. Schmidt, et al. [45] used a functional unit in order to adopt the amount of electricity required for 10,000 citizens in Toronto. The existing photovoltaic system and proposed wind farm are compared in terms of environmental impacts and damage assessment. Although the PV plant demonstrates less damage to human health than the wind system, the wind farm shows lower impact to ecosystems than the PV plant for the Canadian region. 
Table 1. Summary of LCA studies about photovoltaic electricity.

\begin{tabular}{|c|c|c|c|c|c|c|c|c|c|c|c|}
\hline \multicolumn{2}{|c|}{ Phases } & \multicolumn{2}{|c|}{ Installation } & \multicolumn{2}{|c|}{ Solar Cells } & \multicolumn{2}{|c|}{ PV System } & \multirow{2}{*}{$\begin{array}{c}\text { GHGs } \\
{[\mathrm{kg} / \mathrm{MWh}]}\end{array}$} & \multirow{2}{*}{$\begin{array}{c}\text { EPBT } \\
\text { [years] }\end{array}$} & \multirow[b]{2}{*}{ Location } & \multirow[b]{2}{*}{ References } \\
\hline Onset & Final & Roof & Ground & Module Efficiency & Cell Type & On-Grid & Off-Grid & & & & \\
\hline Material choices & Recycling & $\sqrt{ }$ & $\sqrt{ }$ & - & All & $\sqrt{ }$ & $\sqrt{ }$ & - & - & Indonesia & [46] \\
\hline Extraction of raw materials & Recycling & - & $\sqrt{ }$ & $14.4 \%$ & mc-Si & $\sqrt{ }$ & - & 106 & 4.17 & Perugia, Italy & [47] \\
\hline Production & O\&M & - & $\sqrt{ }$ & $12.8 \%$ & multi-Si & 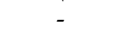 & - & 12.0 & 1.9 & Gobi Desert & [48] \\
\hline Production & O\&M & $\sqrt{ }$ & - & - & multi-si & - & - & $20.9-30.2$ & $1.01-1.08$ & Singapore & [49] \\
\hline Production & Recycling (BOS) & $\sqrt{ }$ & - & $14.2 \%$ & mono-si & - & $\sqrt{ }$ & 0.053 & 2.5 & Copenhagen, Denmark & [50] \\
\hline Production & $\mathrm{O} \& \mathrm{M}$ & $\sqrt{ }$ & - & $14.7 \%$ & multi-si & $\sqrt{ }$ & - & - & 2.33 & Australia & [51] \\
\hline Production & Recycling or disposal & - & $\sqrt{ }$ & - & multi-Si & $\sqrt{ }$ & - & - & 2.3 & China & [52] \\
\hline Production & O\&M & - & $\sqrt{ }$ & $12.8 \%$ & multi-si & $\sqrt{ }$ & - & $13.9-14.9$ & $2.2-2.3$ & Gobi Desert & [53] \\
\hline Production & Disposal & - & $\sqrt{ }$ & - & multi-si & $\sqrt{ }$ & - & with ReCiP & method & Toronto & [45] \\
\hline - & Disposal or recycling & - & - & - & multi-si & 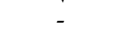 & $\sqrt{ }$ & - & - & - & [54] \\
\hline Production & Disposal & - & $\sqrt{ }$ & $12.2 \%$ & BOS (multi-si) & $\sqrt{ }$ & - & $29 / \mathrm{m}^{2}$ & $0.21-0.37$ & Springerville, USA & [55] \\
\hline
\end{tabular}




\section{System Boundaries and Methodology}

This section introduces the approach of LCA including the framework, assumptions, and related activities. The formulas associated with the LCC are given to demonstrate the calculation part of the life cycle cost section of all technologies.

\subsection{System Boundaries}

In this study, two different configurations of power plants have been selected. As a general assumption, transportations of primary raw materials such as silica and steel are not considered, since the wafer is produced in Taiwan in the case of a photovoltaic power plant and nacelle, rotor, and tower are produced in Germany for the wind farm case. Relevant processes for production of primary raw materials are included, but transportations of related materials, which is necessary for their production, are excluded throughout this study. GaBi is used to establish LCA modelling and assessments. Furthermore, the circular economy approach is applied for scrapping materials for both systems. Other assumptions related to the technologies are listed in Sections 3.1 and 4.1 which are model structure parts for the PV system and wind farm, respectively.

A normalization procedure is applied in order to present the results as a single emission type. In other words, different emissions like acidification potential and eutrophication potential convert into an equivalent quantity of $\mathrm{CO}_{2}$ by means of the normalization process. In this study, CML2001-Jan 2016 database [56] is used from GaBi. For example, the emissions caused by global warming potential are represented as $\mathrm{kg} \mathrm{CO}_{2}$-equivalent. The functional unit of $\mathrm{LCA}$ is taken as the unit of power, $\mathrm{MWh}$. Additionally, $\mathrm{kg} \mathrm{CO}_{2}$-eq./MWh is the measure parameter for global warming potential, $\mathrm{MJ} / \mathrm{MWh}$ is the parameter for cumulative energy demand (CED), year for energy pay-back time, and money for the lifecycle cost.

The main purpose of the study is the comparison of different renewable systems for Bozcaada Island in order to select the most sustainable option. Therefore, the selection of energy mixes is based on the location where the materials are produced, bought, and transported, which is carried out separately for each system and summarized in related assumption tables in the model structure and assumption sections. Section 3.1 for the photovoltaic power plant and Section 4.1 for the onshore wind farm.

\subsection{Life Cycle Assessment (LCA) and Life Cycle Cost (LCC)}

Life cycle assessment can be defined as a method to evaluate environmental characteristics of a system, product or processes [57] and [58].

\subsubsection{Life Cycle Assessment (LCA)}

Life cycle stages are divided into four main phases (namely production, construction, operation and maintenance, and decommissioning and recycling) following the statement in the International Agency Report Methodology Guidelines on Life Cycle Assessment of Photovoltaic Electricity [59].

\section{Production Phase}

It starts with raw material extraction, which includes manufacturing all the components including infrastructure materials and transmission materials utilized to the grid.

\section{Construction Phase}

It starts with transportation of all materials to the operation site. It includes the test procedure for initialization as well as commissioning of the system together with the foundation and supporting structures. 
Operation and Maintenance Phase

It starts with electricity production and it consists of dusting and cleaning and periodic controls of the power plant as a maintenance procedure.

Decommissioning and Recycling (or Disposal) Phase

It includes disassembly of plant parts and decomposition and separation of them for recycling or disposal.

\subsubsection{Life Cycle Cost (LCC)}

The life cycle cost (LCC) is a technique to evaluate all costs during the life cycle [60]. For the case of life cycle costs, design costs containing feasibility and improvements of projects are not considered. In terms of feasibility costs, both systems are renewable and the selected region has high potential for each case, according to the UNIDO project [23]. Project costs might be considered approximately the same for both technologies since the same land is selected for their applications. Since the purpose of the study is to create the framework of the selection between two distinct renewable technologies in terms of life cycle specifications, life cycle costs are divided into three categories. During the procedure, labor costs is not included in LCC calculations since labor costs are expected to be the same due to the requirement of qualified workers for both systems. In this study, the costs of material flows are only considered and are divided into three parts as follows.

Initial Investment Costs

All costs like materials of the systems and construction period are included. Construction costs such as infrastructure for the investments are evaluated in this section for both cases. Costs of material transportation to construction site are included in the initial investment costs.

Operation and Maintenance Costs

Materials required during the operation procedure like lubricants for wind farm and maintenance procedure like tap water for the cleaning of the PV system are considered. The cost of the replacements of components is another item that is included in operation and maintenance costs. The cost of transportations of either the replacements of components or transportation of necessary materials for the maintenance procedure are considered in the operation and maintenance costs even though they have minor effects as opposed to costs of transportation in the initial investment process.

\section{Disposal or Recycling Costs}

Costs for decomposition of the plants and transportation costs for the decomposed materials are included. Decomposed materials are transported to either the recycling facility or to the landfill area for treatment.

In part of the life cycle cost, there is an assumption related to the cost calculation that is the difference between the costs of the projects of two renewable systems, which can be neglected due to the fact that the same land area is selected for both cases. Therefore, Equation (1) is developed for the life cycle cost of renewable energy technologies in the light of the explanations for three cost categories in order to make the comparison possible between two configurations.

$$
\mathrm{LCC}=\mathrm{C}_{\mathrm{inv}}+\mathrm{C}_{\mathrm{O} \& \mathrm{M}}+\mathrm{C}_{\mathrm{DorR}}
$$

where $\mathrm{C}_{\mathrm{O} \& \mathrm{M}}$ indicates operation and maintenance costs, $\mathrm{C}_{\mathrm{inv}}$. and $\mathrm{C}_{\text {DorR }}$ show initial investment costs, and costs of the phase of disposal or recycling, respectively. $C_{\text {inv. }}$ can be utilized as the initial investment cost with the shortage of IIC shown, especially in tables in the rest of the study. 
Details of the costs for the configurations are classified in the associated sections for both the photovoltaic power plant and the wind farm.

\section{Ground-Mounted Photovoltaic Plant}

\subsection{Model Structure and Assumptions}

In this section, a ground mounted photovoltaic system is proposed on the site that is currently the location of Bozcaada wind farm (see Figure 1). The total area of wind farm is taken as $20,560 \mathrm{~m}^{2}$ based on discussions with experts from the operating company. Since this study aims to compare two configurations, the total area of the PV system should be considered close to this area. Moreover, land-use requirement of fixed-tilt PV system is estimated by Denholm and Margolis [61] as 3.8 acres/MWac in the United States. The land use requirement is calculated as $17,391 \mathrm{~m}^{2} / \mathrm{MW}$ for the Konya Plain Region [62] even though there is no information for the Bozcaada region. The PV system capacity can be estimated to be approximately 1.2 MW for the same land area of wind farm since land occupation for $1 \mathrm{MW}$ photovoltaic plant is around $16,400 \mathrm{~m}^{2}$, which was calculated by taking the average of land use requirements stated for the U.S. and Turkey.

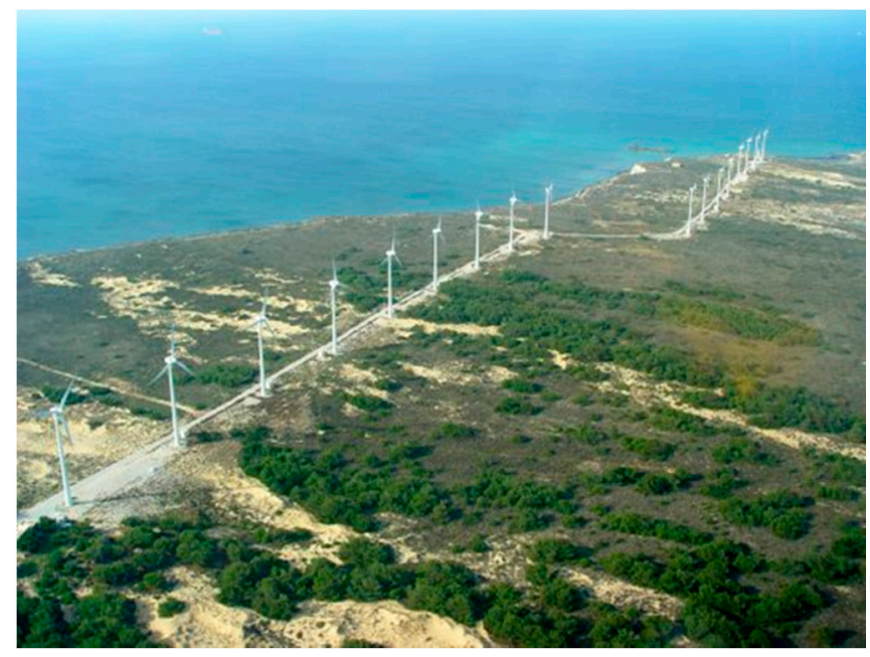

Figure 1. Selected site on Bozcaada Island [63].

Due to long exposure time of environmental conditions, the efficiency of solar panels decreases. This is called degradation. The main factors of degradation are regarded as temperature differences and humidity conditions and soiling of solar panels. Total energy production should be estimated correctly with appropriate degradation ratio. Therefore, the overall system degradation ratio for the photovoltaic system based on polycrystalline cells are assumed to be $0.6 \%$ per year for this study [64].

The lifetime of the photovoltaic power plant is assumed to be 30 years, according to the list, which is in the part of lifetime [65].

The performance ratio is another important factor in order to predict total energy production of the proposed photovoltaic system throughout its life. The performance ratio can be defined as the ratio of actual output and theoretical output for an ideal case. In other words, in real life, actual electricity production of a PV system is less than the calculated one for an ideal case. For this purpose, the appropriate performance ratio is substantial for predicting total energy production. According to Karadogan et al. [66], on-grid applications of the photovoltaic system was started in 2012 in Turkey. Therefore, actual data for electricity production of these systems is not sufficient to estimate a reliable performance ratio in Turkey. In the previously mentioned study [66], it has been found that the deviation between the real energy production and the estimated values for electricity production for seven PV power plants in different sites of Turkey is around $5.54 \%$ and, in most of the cases in the study, 
the Photovoltaic Geographical Information System (PVGIS) database demonstrates closer results. Therefore, the PVGIS calculator is utilized for the expected electricity production of the proposed PV power plant for this study. The performance ratio of the photovoltaic system is determined to be 0.80 by the PVGIS calculator. This performance ratio is also recommended for a ground mounted system [67]. In the PVGIS calculator, the optimum design is selected for the array of solar panels with $32^{\circ}$ slope and $3^{\circ}$ azimuth angles for Bozcaada Island.

Assumptions based on the photovoltaic system are listed in Table 2.

Table 2. Assumptions for the proposed PV system.

\begin{tabular}{ccc}
\hline \multicolumn{2}{c}{ PV system Assumptions and Specifications } & Comments \\
\hline Nominal power of photovoltaic plant & $1.2 \mathrm{MW}$ & Extrapolation with land-use for 1 MW \\
Area of plant for infrastructure & $20,560 \mathrm{~m}^{2}$ & Established wind farm area \\
Plant area & $16,400 \mathrm{~m}^{2}$ & Land requirement for 1MW \\
Performance ratio & 0.80 & PVGIS database and Reference [67] \\
Degradation ratio & $0.6 \%$ & {$[64]$} \\
Lifetime of the plant & 30 years & [65] \\
Lifetime of the inverters & 15 years & \\
\hline Lifecycle inventory assumptions & Including processes excluding transportation \\
Production up to wafer & In Taiwan & No Taiwanese grid mix in GaBi \\
Electricity mix & Chinese & 8689 nautical miles as shortest route \\
Transportation of wafers & By ocean-going ship & Assembly with metallization pastes and wafers \\
Production of solar cell & In Turkey & Ground mounting structures (aluminum frames) \\
Production of other parts & In Turkey & No Turkish grid mix and production in Tekirdag \\
Electricity mix & Bulgarian mix & By ferry to island \\
Transportation to site & By truck and ferry & No Turkish grid mix (for installation) \\
Initialization & Greek mix & Carrying waterand replacements of broken \\
Operation and Maintenance & By truck & panels and inverters \\
\hline
\end{tabular}

In this study, the Eco-Invent database is used for components and processes for the life cycle inventory of the photovoltaic power plant.

\subsection{Life Cycle Inventory (LCI) of the Photovoltaic System}

All components in order to establish the 1.2 MW photovoltaic power plant are listed in Table 3.

Table 3. Configurations of the proposed PV system.

\begin{tabular}{cc}
\hline \multicolumn{2}{c}{ List of Materials for Solar Cells } \\
\hline Nominal power of the solar module & $265 \mathrm{Wp}$ \\
Number of solar module & $4615+15$ \\
Number of solar cell in a module & 60 \\
Number of solar cell & 277,800 \\
Area of one solar cell & $243 \mathrm{~cm}^{2}$ \\
Area of photovoltaic modules & $6855 \mathrm{~m}^{2}$ \\
\hline List of materials used for the support structure (open ground mounting structure) \\
\hline Steel, zinc coated & $3909 \mathrm{~kg}$ \\
Aluminum & $3111 \mathrm{~kg}$ \\
\hline
\end{tabular}

They include solar panels consisting of multi-crystalline cells, inverters, support structures, containing foundation and fence equipment, and are named as an open ground mounting structure in the rest of the study, and electrical components are comprised of cables, low and medium voltage switchboards.

Multi-crystalline solar cells can be produced in Turkey after raw material extraction, which is silicon wafer. Solar cells are made from metallurgical grade silicon. The Bulgarian grid mix is used 
to produce solar cells since there is no available data for the Turkish grid mix. In addition to this, raw materials are obtained from Taiwan for multi-Si technologies by the selected local company. The Chinese grid mix is used until solar cell production due to the fact that there is no data available for the Taiwanese grid mix. In the production phase, silicon wafers from Taiwan transported by an ocean-going ship and transportation distance is assumed as 8689 nautical miles. Inverter and open ground mounting structure are transported to the site in the construction phase.

The infrastructure requires cleaning of the area and construction of the building, which is necessary for the operation stage. Additionally, it requires roads between arrays due to the requirement of the maintenance period including cleaning solar cells with acetone and changing broken ones. Therefore, in the production stage, necessary materials for infrastructure are added to the open ground mounting structure process to be transported to the site area. The open ground mounting structure process is created as a unit process. Material and energy flows are added to the related process in $\mathrm{GaBi}$. Fence and foundation parts are considered by means of relevant flows inside this process.

For construction, first, the raw material extraction phase excluding transportation is completed. Following this, solar modules, open ground mounting structure, and inverters are transported to the site for assembling the power plant. The transportation distance for solar modules produced in Tekirdag is $291 \mathrm{~km}$. The distance between the city and Kilitbahir ferry dock is $228 \mathrm{~km}$. After $2 \mathrm{~km}$ by ferry, the distance between Geyikli and Çanakkale ferry docks is $54 \mathrm{~km}$ by truck. Lastly, the distance along the Bozcaada ferry dock up to the construction site is $9 \mathrm{~km}$. Distances for transportation are shown in Table 4 in the section of the life cycle cost.

As the initialization procedure, a unit process is first generated in $\mathrm{GaBi}$ and named as electric installation with the extrapolation from $570 \mathrm{kWp}$ photovoltaic plant in the database [68] in order to observe mass and energy flows related lightning protection, cabling in the module area, cabling from the module to the inverter, cabling from the inverter to the electric meter, and the weight of the fuse box. In order to finalize the construction phase, a unit process named as the PV plant installation is created. Additionally, the Greek electricity mix is used to initiate electricity production on this process.

Operation and maintenance stages are considered in the third phase. The utilization of tap water for the cleaning of the solar cell is assumed as the main maintenance procedure of solar modules. In the case of cleaning procedure (throughout the whole life), the transportation distance of truck carrying tap water is assumed to be $80 \mathrm{~km}$. Another procedure for the maintenance is the change of 15 solar modules, which are assumed to break during the lifespan of the plant. In addition, all inverters are changed once since their lifetime is accepted as 15 years, according to the list for the PV system component [65] during the operation phase. Total transportation distance for square parts containing the inverters and 15 broken solar cells is assumed to be $80 \mathrm{~km}$. Total electricity production throughout the whole life of a power plant is estimated to be $52.31 \mathrm{GWh}$ with a $0.6 \%$ annual degradation rate and an $80 \%$ performance ratio, which are shown in Figure 2.

Lastly, as the fourth phase, which is the deconstruction and recycling stage, two distinct recycling procedures are investigated. For the first case, with the end of life approach, on-site basic deconstruction is assumed. A unit process is created in the software for the recycling procedure. Aluminum, copper, and steel scrap from frames and inverters coming from the balance of the system components are evaluated as recycling materials, and their weights are calculated separately, and solar panels are added to the previously mentioned unit process, which is named as the total weight of solar panels. The rest of the material are added as municipal waste to the structural scrap materials process. Scrap materials and solar modules called structural scrap materials are transported to İzmir, which is $300 \mathrm{~km}$ far away from the construction site for the recycling procedure. In the Izmir region, aluminum, copper, and steel scraps from the balance of system can be recycled. However, there is no recycling technology for solar panels in Turkey. The end-of-life approach is applied for solar panels by creating a takeback and recycling unit process and avoid the burden form solar module unit process. According to Frischknect et al. [59], the end-of-life approach is based on the recycling of glass from solar modules. In this approach, there is no exact information related to the recycling process for other materials such 
as silicon wafer and metallization pastes. The unit process is defined based on the recycling technology for glass in the end-of life approach.

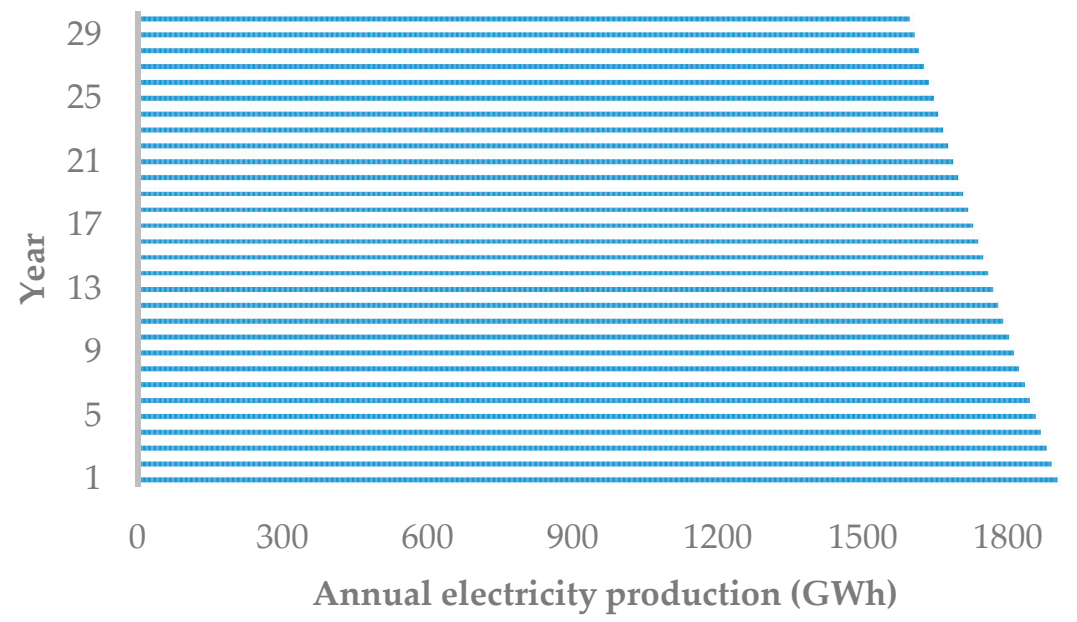

Figure 2. Prediction of electricity production from the PV plant during its life cycle.

As the second case, named as the real recycling plant case, like in the similar case study [47] deconstruction and recycling or disposal stage, disposed solar panels are transferred to the Deutsche Solar AG recycling plant [69] by a cargo plane and only recycled solar modules, with $3.48 \%$ mass fraction of total solar panels, are transferred back to the construction site by a truck since there is no recycling plant for solar cells in Turkey. During the first transfer part of the second case, transportation by ferry and truck are neglected due to the fact that a cargo plane is considered for the main transportation vehicle.

Open loop recycling is applied for other parts except solar panels.

In the rest of the study, the first case is mentioned as recycling with the end-of life approach and the second case is named as the real recycling plant case.

In the comparison part of the technologies, which is Section 5 , a real recycling plant case is utilized for the photovoltaic power plant in order to make a realistic comparison between the technologies since recycling with the end-of-life approach is an imaginary scenario based on the imaginary recycling plant in İzmir.

\subsection{Life Cycle Cost (LCC) of the Photovoltaic System}

The LCC model of the PV plant is applied, according to Equation (2), which is adopted with the aid of the LCC equation in the article of Abu-Rumman et al. [70] and the LCC equation, Equation (1), which is developed for this study. Therefore, Equation (2) is utilized for the calculation of the life cycle cost of PV configurations.

$$
\mathrm{LCC}_{\mathrm{PV}}=\mathrm{C}_{\text {panels }}+\mathrm{C}_{\mathrm{P}_{\text {elec }}}+\mathrm{C}_{\mathrm{P}_{\text {inf }}}+\mathrm{C}_{\mathrm{P}_{\mathrm{O} \& \mathrm{M}}}+\mathrm{C}_{\mathrm{P}_{\text {tr }}}
$$

where

$$
\mathrm{C}_{\mathrm{P}_{\text {inv }}}=\mathrm{C}_{\text {panels }}+\mathrm{C}_{\mathrm{P}_{\text {inf }}}+\mathrm{C}_{\mathrm{P}_{\text {elec }}}+\mathrm{C}_{\mathrm{P}_{\mathrm{t} 1}} \text {, }
$$

and

$$
\mathrm{C}_{\mathrm{P}_{\mathrm{tr}}}=\mathrm{C}_{\mathrm{P}_{\mathrm{t} 1}}+\mathrm{C}_{\mathrm{P}_{\mathrm{t} 2}}+\mathrm{C}_{\mathrm{P}_{\mathrm{t} 3}}
$$

In the above equations, $C_{P_{t r}}$ is the total transportation costs from cradle to grave. In addition to this, $\mathrm{C}_{\mathrm{P}_{\mathrm{t} 1}}, \mathrm{C}_{\mathrm{P}_{\mathrm{t} 2}}$, and $\mathrm{C}_{\mathrm{P}_{\mathrm{t} 3}}$ are the transportation costs of three categories. In other words, transportation 
costs for the initial investment is $C_{P_{t 1}}, C_{P_{\mathrm{t} 2}}$ is transportation costs for the operation and maintenance procedure, and, lastly, $\mathrm{C}_{\mathrm{P}_{\mathrm{t} 3}}$ is the transportation cost for disposal or recycling. Therefore,

$$
\mathrm{C}_{\mathrm{P}_{\mathrm{O \& M}}}=\mathrm{C}_{\text {tap water }}+\mathrm{C}_{\mathrm{spare} \mathrm{panels}}+\mathrm{C}_{\mathrm{P}_{\mathrm{t} 2}}
$$

and

$$
\mathrm{C}_{\mathrm{P}_{\text {DorR }}}=\mathrm{C}_{\mathrm{P}_{\mathrm{t} 3}, \ldots}
$$

Details for transportation costs are summarized in Table 4.

The costs of solar panels are calculated with the price of solar panels for the selected company in Tekirdag.

Infrastructure costs for a photovoltaic system requires site preparation initially. However, there is no need for the selected area, as seen in Figure 1 since the selected region has no meaningful slope and there is no vegetation that prevents the application. During site clearance for the infrastructure of the PV system, general cleaning will be sufficient. Therefore, no material flows are considered for general cleaning of the infrastructure. Furthermore, there is the assumption of the elimination of labor costs to make the comparison easier between the renewable configurations with the estimation of approximately equal labor costs for both systems. Therefore, the open ground mounting structure cost can be regarded as one of the sources of the costs for the infrastructure of the photovoltaic power plant. For the costs of open ground mounting structure, the costs of settings, wiring etc. [71] for $1 \mathrm{~kW}$ is extrapolated with the inflation rate of Turkey [72] since the production of all other materials except the wafer is assumed to be produced in Turkey. Another source of the infrastructure is the costs of the building and landscape. The working area, which will be used for the operation procedure, is assumed to be $100 \mathrm{~m}^{2}$ and its costs is assumed to be $\$ 34,180$ as in the wind farm case. $C_{P_{\text {elec }}}$ consists of the costs of inverters and $9 \mathrm{~km}$-cables either between solar panels or the transmission line to the grid. The Turkish inflation rate is applied to the cost of the grid tie inverter price [71] to obtain the costs of an electrical apparatus containing cables for this study.

\begin{tabular}{|c|c|c|c|c|c|}
\hline Materials & Weight (kg) & By Truck (km) & By Ferry (km) & $\begin{array}{c}\text { Transportation } \\
\text { Costs }\end{array}$ & $\begin{array}{c}\text { Cost } \\
\text { Categories }\end{array}$ \\
\hline Solar panels & 77,840 & 291 & 10 & $\$ 171.56$ & IIC \\
\hline $\begin{array}{l}\text { Open ground mounting } \\
\text { structure }\end{array}$ & 8990 & 390 & 8 & $\$ 135.50$ & IIC \\
\hline Inverters & 9849 & 451 & 8 & $\$ 878.01$ & IIC \\
\hline Spare inverters & 9849 & $451+80$ & 8 & $\$ 1032.60$ & O\&M \\
\hline Spare solar panels & 252 & $291+80$ & 10 & $\$ 218.72$ & O\&M \\
\hline Tap water & 46,593 & 80 & - & $\$ 372.20$ & O\&M \\
\hline Solar panels for recycling & 77,776 & \multicolumn{2}{|c|}{ Without ferry and truck (with cargo plane) } & $\$ 8525.77$ & DorR \\
\hline Aluminum scrap & 3111 & 300 & 8 & $\$ 71.70$ & DorR \\
\hline Copper scrap & 1100 & 300 & 8 & $\$ 33.04$ & DorR \\
\hline Steel scrap & 8636 & 300 & 8 & $\$ 111.44$ & DorR \\
\hline
\end{tabular}

Table 4. Transportation costs for the materials of the photovoltaic power plant.

The costs of operation and maintenance are based on costs of the replacements of spare parts and cost of cleaning the solar panels. Throughout the life of the photovoltaic plant, 46.6 tons tap water is utilized and its transportation distance is assumed to be $80 \mathrm{~km}$ similar to the replacement distance for the inverters and spare parts, which are broken solar panels, as seen in Table 4. Spare solar panels and spare inverters are not allocated initially due to the difficulty of their protection. Hence, their transportation distances are added to the transportation distances of the original parts.

Transportation costs as seen in Table 4 are related to the weight of materials and distances of the materials and are calculated based on the consumption of diesel. Diesel consumptions are taken from GaBi and the price of diesel is found in the archived list of the BP company [73]. Ultimate diesel price for Istanbul is utilized for the calculation procedure. Solar panels for recycling are transferred with a cargo plane. Kerosene price [74] is taken from the Alibaba website as $\$ 300 /$ tons. 
Results of the life cycle costs of not only the PV system but also the wind farm are compared in the life cycle cost analysis part.

\section{Onshore Wind Farm}

\subsection{Model Structure and Assumptions}

As seen in Figure 1, there is a wind farm consisting of 17 wind turbines with a linear arrangement. The wind farm has 10.2 MW installed capacity with Enercon E-40 (600 kW) wind turbines [75]. It covers $20,560 \mathrm{~m}^{2}$ and it is located on the west-side of Bozcaada Island. Tower height is taken as $44 \mathrm{~m}$ based on discussions with the experts from the operating company. Considering environmental impacts, the company decided to paint the wind farm using an earth color and to connect turbines by underground wiring which is $9 \mathrm{~km}$ long to the central transformer of the island in order to preserve the natural appearance of the island.

Assumptions for the wind farm and the basic characteristics of the wind farm are listed in Tables 5 and 6 , respectively.

Enercon E-40 type wind turbines were used in Bozcaada Island. However, there are no detail data for the case of specific tower height on the manufacturer's website. Therefore, tower weight is utilized from the work [76] since tower height is $46 \mathrm{~m}$ in that work and it is $44 \mathrm{~m}$ in Table 5 .

There is no production line for this kind of turbine in Turkey when this wind farm was installed to operate. Therefore, wind turbines are transported from Enercon Company in Germany by truck in the modelling procedure. Transportation distances between Bozcaada Island and Enercon Company in Germany are measured using google maps as $2640 \mathrm{~km}$ by truck and $8 \mathrm{~km}$ by inland ship to reach Bozcaada Island.

Cables and an inverter for electric installation of the farm were brought from the company's own cable factory in Bilecik. Hence, transportation distance for them was $441 \mathrm{~km}$ by truck and $8 \mathrm{~km}$ by ferry.

There is no information about acquisition of concrete materials. Hence, transportation distance of concrete is assumed to be $305 \mathrm{~km}$.

Table 5. Assumptions for the wind farm.

\begin{tabular}{|c|c|c|}
\hline \multicolumn{2}{|c|}{ Wind Farm Assumptions and Specifications } & Comments \\
\hline Nominal power of photovoltaic plant & $10.2 \mathrm{MW}$ & Established wind farm capacity \\
\hline Area of plant for infrastructure & $20,560 \mathrm{~m}^{2}$ & Established wind farm area \\
\hline Average produced electricity per year & $34 \mathrm{GWh}$ & From the discussion with operating company \\
\hline Lifetime of the plant & 20 years & {$[43]$} \\
\hline \multicolumn{3}{|c|}{ Lifecycle inventory assumptions } \\
\hline Production up to wind turbine & In Germany & Including processes excluding transportation \\
\hline Electricity mix & Deutch & Production in Germany \\
\hline Transportation of wind turbines & By truck & $2640 \mathrm{~km}$ \\
\hline Production of other parts & In Turkey & Concrete, cables, and inverters \\
\hline Electricity mix & Bulgarian mix & No Turkish grid mix and production in Turkey \\
\hline Transportation of other parts & By truck & 305 and $441 \mathrm{~km}$ for concrete and cables and inverters \\
\hline Transportation to site & By truck and ferry & By ferry to the island \\
\hline Initialization & Greek mix & No Turkish grid mix (for installation) \\
\hline Operation and Maintenance & By truck & $3400 \mathrm{~kg}$ lubricant [77] \\
\hline
\end{tabular}

In $\mathrm{GaBi}$, cables and inverter, nacelle, foundations and roads, tower, and rotor are created as a unit process. However, transportation of primary raw material such as cast iron is not considered since the production line for basic components of wind turbine is in Germany. Although other components such as foundations, roads, cables and inverters are produced in Turkey. Transportation distance for their raw materials are neglected in this study. 
Table 6. Basic characteristics of wind farm.

\begin{tabular}{lc}
\hline \multicolumn{1}{c}{ Onshore Wind Farm on Bozcaada Island } \\
\hline Location of the wind farm & West side of the island \\
Number of turbines & 17 \\
Nominal power of turbine & $600 \mathrm{~kW}$ \\
Underground wiring between turbines & $9 \mathrm{~km}$ \\
Rotor diameter* & $43.7 \mathrm{~m}$ \\
Tower height & $44 \mathrm{~m}$ \\
\hline
\end{tabular}

Note: *: It is taken from [78].

\subsection{Life Cycle Inventory (LCI) of Onshore Wind Farm}

Specifications of Enercon E-40 (600 kW) wind turbines are demonstrated in Table 7. Tower weight is reduced by means of linear interpolation technique to correct material flows. Furthermore, the total weight is decreased for material requirement calculations.

Table 7. Enercon E-40 (600 kW) specifications [78].

\begin{tabular}{cc}
\hline \multicolumn{2}{c}{ Enercon E-40 Wind Turbine } \\
\hline Power capacity & $0.60 \mathrm{MW}$ \\
Rotor diameter & $43.70 \mathrm{~m}$ \\
Tower height & $44.00 \mathrm{~m}$ \\
Rotor weight & 8.27 tons \\
Nacelle weight & 19.77 tons \\
Tower weight & 29.91 tons \\
Base weight & 220.00 tons \\
Total weight & 277.95 tons \\
\hline
\end{tabular}

As a beginning, the wind farm is divided into two parts as a fixed part of the wind turbine and moving parts of the wind turbine, which are compatible with GaBi flows. Moving parts of the wind power plant compromises of cables, inverters, nacelle, and rotor.

\subsubsection{Moving Parts of the Wind Turbine}

Moving parts of the wind turbine contains nacelle, rotor, cable, and an inverter for this study. The transportation distance assumed as $441 \mathrm{~km}$ for cables. In $\mathrm{GaBi}$, a unit process is created to mimic cables and the inverter.

Nacelle

It was the main parts of the wind turbine for housing the generator, gearbox, and brakes. It was produced in Germany. It contains steel and a cast-iron part. As a process, the metal roll forming process [79] was applied for its production in GaBi. Nacelle is transported to the construction site by ferry.

\section{Rotor}

The rotor contains a hub and blades. Glass fiber, epoxy resin, and cast iron are the materials for its production. It is another component from the moving parts of the turbine.

\subsubsection{Moving Parts of the Wind Turbine}

It includes tower and foundations as well as access roads requiring to not only construct but also to maintain the wind farm. 
Tower

It is a painted steel tube. The main function of it is carrying the rotor and nacelle. As a process, metal roll forming [79] applied for its production in $\mathrm{GaBi}$ is similar to nacelle production. The energy requirement of the process and cast-iron parts Deutsch grid mix is selected due to the production of it in Germany when the plant was established.

\section{Foundations and Roads}

The foundation is necessary for assembling a wind turbine on it. Access roads are constructed to carry out maintenance in order to unite whole turbine components. Concrete and steel are the main materials to model its production. In the disposal procedure, foundations and roads are left on the plant site in order to construct a new plant in the future.

The lifespan of the wind farm is assumed to be 20 years [43] for this study.

When extraction of the raw materials phase is finalized, in the construction phase, which is the second phase for the life cycle assessment, moving parts of the wind turbine and the fixed part of wind turbine are connected to turbine assembly by means of the excavator for construction since there is no crane or lifter in GaBi. This is one of the limitations of this study.

As a third phase, operation and maintenance procedures are defined as the use phase above. Energy production from the wind farm is calculated as $680 \mathrm{GWh}$ for the entire life cycle. Furthermore, the wind farm requires four types of periodic controls based on discussions with the operator of the plant. Visual controls are one of the periodic controls, but there is no material flow for it. Second type of periodic control is oiling of the parts. Therefore, lubricants are required for the maintenance stage. The lubricant requirement for the power plant calculated as $3400 \mathrm{~kg}$ throughout the 20-year life of the plant, according to the report [77], and its transportation distance is assumed to be $300 \mathrm{~km}$. According to a discussion with the operator, there are failures of moving parts especially electronic devices. For spare parts, replacement of $1 \%$ of moving parts of the wind turbine is assumed and added to material flow as spare parts. In addition to information taken from the operators, wind turbines require mechanical maintenance twice a year [80]. Site maintenance is neglected since spare parts allocated initially and there is no requirement for access roads due to the fact that the area has no traffic except a maintenance procedure.

In the fourth phase, which is deconstruction and disposal or recycling phase, onshore wind plant decomposed into the main production components including tower, nacelle, rotor, foundation, and decomposition of electronic parts coming from cables and inverters. The end of-life treatment for foundation is 100\% landfill as in the DTU International Energy Report [81] and Haapala and Prempreeda [44] advised. Decomposition of electronic parts is sorted as waste for disposal and aluminum scrap. The landfill process is applied for a decomposed rotor since recycling of the composite is not an easy task for the current technology [81]. Nacelle and tower are decomposed as decomposition for iron sorting and its end-of life treatment is applied as $90 \%$ recycling materials and $10 \%$ landfill. In the recycling phase, open loop recycling is applied since recycling strategies are beyond the aim of the study. Recycling of electronic parts is assumed to be $95 \%$ recycling and $5 \%$ landfill.

Treatment of materials and material quantities is demonstrated in Table 8. For open loop recycling, transportation distances utilized during the end of-life treatment are seen in Table 9 in the life cycle cost of the wind farm. 
Table 8. End of-life summary.

\begin{tabular}{ccccc}
\hline Name of the Components & Treatment & Ratio & Materials Treated & Mass of Components \\
\hline \multirow{2}{*}{ Nacelle + tower } & Landfill & $10 \%$ & Iron & \multirow{2}{*}{845 tons } \\
& Recycling & $90 \%$ & Composite & 142 tons \\
\hline Rotor & Landfill & $100 \%$ & Concrete & 3740 tons \\
\hline Foundation & Landfill & $100 \%$ & \multirow{2}{*}{132 tons } \\
\hline \multirow{2}{*}{ Decomposition of electronic parts } & Landfill & $5 \%$ & \multirow{2}{*}{ Aluminum } & \\
& Recycling & $95 \%$ & &
\end{tabular}

\subsection{Life Cycle Cost (LCC) of Onshore Wind Farm}

The LCC model of the wind farm is applied according to Equation (7), which is adopted with the aid of the LCC equation in the article [82] and developed the LCC equation for this study, which is Equation (1). Therefore, for this study, Equation (7) is utilized for calculating the life cycle cost of the wind farm.

$$
\mathrm{LCC}_{\mathrm{ONW}}=\mathrm{C}_{\text {turbines }}+\mathrm{C}_{\mathrm{W}_{\text {elec }}}+\mathrm{C}_{\mathrm{W}_{\text {inf }}}+\mathrm{C}_{\mathrm{W}_{\mathrm{O \&} \mathrm{M}}}+\mathrm{C}_{\mathrm{W}_{\text {tr }}}
$$

where

$$
\mathrm{C}_{\mathrm{W}_{\text {inv }}}=\mathrm{C}_{\text {turbines }}+\mathrm{C}_{\mathrm{W}_{\text {inf }}}+\mathrm{C}_{\mathrm{W}_{\text {elec }}}+\mathrm{C}_{\mathrm{W}_{\mathrm{t} 1}} \text {, }
$$

and

$$
\mathrm{C}_{\mathrm{W}_{\mathrm{tr}}}=\mathrm{C}_{\mathrm{W}_{\mathrm{t} 1}}+\mathrm{C}_{\mathrm{W}_{\mathrm{t} 2}}+\mathrm{C}_{\mathrm{W}_{\mathrm{t} 3}} \text {, }
$$

In the above equations, $\mathrm{C}_{\mathrm{W}_{\mathrm{tr}}}$ is the total transportation costs from cradle to grave. In addition to this, $C_{W_{\mathrm{t} 1}}, C_{W_{\mathrm{t} 2}}$ and $C_{W_{\mathrm{t} 3}}$ are transportation costs of three categories. In other words, transportation costs for the initial investment is $\mathrm{C}_{\mathrm{W}_{\mathrm{t} 1}}, \mathrm{C}_{\mathrm{W}_{\mathrm{t} 2}}$ is transportation costs for the operation and maintenance procedure, and, lastly, $\mathrm{C}_{\mathrm{W}_{\mathrm{t} 3}}$ is the transportation cost for disposal or recycling. Therefore,

$$
\mathrm{C}_{\mathrm{W}_{\mathrm{O \&} \mathrm{M}}}=\mathrm{C}_{\mathrm{W}_{\mathrm{M}}}+\mathrm{C}_{\mathrm{W}_{\mathrm{t} 2}}
$$

and

$$
\mathrm{C}_{\mathrm{W}_{\text {DorR }}}=\mathrm{C}_{\mathrm{W}_{\mathrm{t} 3}} \text {, }
$$

where $C_{W_{M}}$ is the material costs in the operation and maintenance phase.

During the calculation of costs for infrastructure and costs of electrical apparatus are extrapolated from the cost [83] and [84]. For example, the costs of foundation and roads is calculated to be $\$ 136,724$ by means of the previously mentioned study [84] for the year 2015. The building and landscape area is assumed to be $100 \mathrm{~m}^{2}$ and its cost is taken as $\$ 34,180$. $C_{W_{\text {inf }}}$ is determined as $\$ 170,904$, which is the sum of the costs of foundation and roads and the costs of the building and landscape area. Following that, the Turkish inflation rate is applied to the costs to reach the infrastructure costs for 2019 with the aid of the inflation calculator [72] for Turkish Republic in order to be able to make a comparison between two renewable configurations.

The same procedure is conducted for $\mathrm{C}_{\mathrm{W}_{\text {elec }}}$ since cables and inverters are also assumed to be produced in Turkey. In the case of $C_{\text {turbines }}$, first, one of the Enercon E-40 turbine cost is found from the article [85] in the year 2006.

Total turbine costs are calculated and extrapolated with the producer price indices [86] by using Germany's price indicator.

The operation and maintenance costs consist of the costs of lubricants, transportation costs of spare parts for the necessary replacements, and transportation cost of lubricants when labor costs are excluded from operation and maintenance costs based on the assumptions made in the beginning of the life cycle cost section. The costs of spare parts are considered in the initial investment costs since the allocation of them is conducted before the initialization of the wind farm. The cost of the maintenance procedure, which is basically independent of size [87] and includes replacements of 
spare parts and lubricants is found in the article [88] as $\$ 5770.77$ for the Enercon E-40 turbine. It is extrapolated with the quarterly producer price indices [86] by using Germany's price indicator since the prices of lubricants and other consumables are increased between 2008 and 2019.

Costs of transportation due to scrap materials are calculated by means of the weights and hauls of scrap materials. They are calculated based on the consumption of diesel. Diesel consumptions of the transportation process for all scrap materials are taken from $\mathrm{GaBi}$ and the price of diesel is calculated by means of the archived list of the BP company like in the life cycle cost of the photovoltaic plant. The ultimate diesel price for Istanbul is utilized for the calculation procedure. The procedure mentioned above and results are listed in Table 9.

Table 9. Transportation costs for the materials of the wind farm.

\begin{tabular}{cccccc}
\hline Materials & Weight (t) & By Truck $\mathbf{( k m )}$ & By Ferry (km) & $\begin{array}{c}\text { Transportation } \\
\text { Costs }\end{array}$ & $\begin{array}{c}\text { Cost } \\
\text { Categories }\end{array}$ \\
\hline Nacelle & 336 & 2640 & 8 & $\$ 24,009$ & IIC \\
Rotor & 142 & 2640 & 8 & $\$ 15,925$ & IIC \\
Cables and inverter & 132 & 441 & 8 & $\$ 2275$ & IIC \\
Foundation and roads & 3740 & 305 & 8 & $\$ 28,187$ & IIC \\
Tower & 508 & 2640 & 8 & $\$ 31,735$ & IIC \\
Spare parts & 6.1 & 300 & Allocated & $\$ 141$ & O and M \\
Lubricants & 3.4 & 300 & 8 & $\$ 34$ & O and M \\
Iron & 845 & 100 & 15 & $\$ 2712$ & DorR \\
Composite & 142 & 100 & 15 & $\$ 681$ & DorR \\
Concrete & 3740 & - & - & Landfill & DorR \\
Aluminum & 132 & 100 & 15 & $\$ 424$ & DorR \\
\hline
\end{tabular}

Results of life cycle costs of the wind farm are compared with the cost of the PV plant in a life cycle cost analysis.

\section{Results}

In this section, environmental quantities of both the onshore wind farm and the photovoltaic power plant are described and compared.

Average annual electricity production is $34 \mathrm{GWh} /$ year for the wind farm and $1.74 \mathrm{GWh} /$ year for the PV plant, respectively.

\subsection{Life Cycle Impact Assessment (LCIA)}

Primary energy demands from renewable and non-renewable resources (net calorific value) for onshore wind farm and photovoltaic power plant are 71,160,356.64 MJ and 12,268,381.46 MJ, respectively.

Cumulative energy demand values are calculated for each system by using the primary energy requirement values as in the study [89]. The ratio of the total energy embedded in the system as the primary energy [90] and average annual electricity production is defined as energy payback time for this study. Energy pay-back time values for not only onshore wind farm but also the photovoltaic power plant can be seen in Table 10.

The CML2001-Jan 2016 [56] method is utilized for all environmental quantities including global warming potential, acidification potential and eutrophication potential.

Air pollution is caused by acid rain and it leads to air pollution [91]. Air pollution and eutrophication are the major reasons for water pollution. Both acidification and eutrophication are considered as other environmental impact categories for this study due to the selection of the location, which is an island to be established as the renewable energy generation systems.

Acidification potential of the PV system is shown in Figure 3 and acidification potential of onshore wind farm is shown in Figure 4 whereas eutrophication potential of PV system is shown in Figure 5 and eutrophication potential of the onshore wind farm is shown in Figure 6. In the case of the PV 
system, the production phase leads to the highest acidification level as expected due to extensive energy requirements from different sources such as thermal energy and electricity. Similar to the production phase of the PV plant, the disposal or recycling phase causes a high acidification level due to the need of fuel for transportation of scrap materials. As seen in Figures 3 and 4, the construction phase for the onshore wind farm demonstrates a higher acidification level than the photovoltaic power plant. During the production process for the wind turbine, the unit process of aluminum ingot mix is the main contributor of acidification in the case of onshore wind farm. In the production phase of the photovoltaic power plant, the energy requirement processes either thermal energy or electricity and the unit process of float flat glass can be regarded as the major cause for the acidification. As seen in Figure 4, the acidification potential of the disposal or recycling phase of the PV system is another highest share due to the airline transport of the scrap materials to the real recycling plant.

In terms of eutrophication level, the disposal or recycling phase of onshore wind farm demonstrates the highest one due to a disposal or recycling phase. The unit process of municipal solid waste on landfill which derived from the disposal of foundation and roads, is the major reason of high eutrophication. Furthermore, the result of the production phase of onshore wind farm does not indicate the specific unit process like in the case of disposal or recycling phase of the wind farm when the results are examined in detail. In the case of eutrophication, the production of multi-Si wafer can be regarded as another cause as well as the energy requirement of the processes and the unit process of float flat glass for the first phase of the PV system. The unit process of the cargo plane has the biggest share in the disposal or recycling phase of the photovoltaic plant in terms of the eutrophication level like in the acidification potential.

Global warming potential of the photovoltaic power plant and the onshore wind farm are shown in Figures 7 and 8, respectively. While total GWP of the PV system is $958,858.26 \mathrm{~kg} \mathrm{CO}_{2}$-eq., total GWP of the onshore wind farm is $7,194,780.48 \mathrm{~kg} \mathrm{CO}_{2}$-eq.

As seen in Figure 9, the ratio of energy demand of the production phase for the PV power plant is $91.738 \%$ whereas the second most energy required phase is disposal or recycling with the ratio of $7.923 \%$. The least energy requirement phase is operation and maintenance. The construction phase needs $0.333 \%$ of total energy demand in the case of the photovoltaic power plant.

In the case of the onshore wind farm (Figure 10), the most energy required, which is, $92.208 \%$, is the production phase like in the case of the PV system. However, the construction phase of the wind farm, which is, $4.104 \%$, needs more than the disposal or recycling of the onshore wind farm, which is, $3.493 \%$, unlike in the photovoltaic power plant. The energy requirement of the operation and maintenance phase for the onshore wind farm, which is, $0.195 \%$, shows a similar trend like in the case of the PV system. 


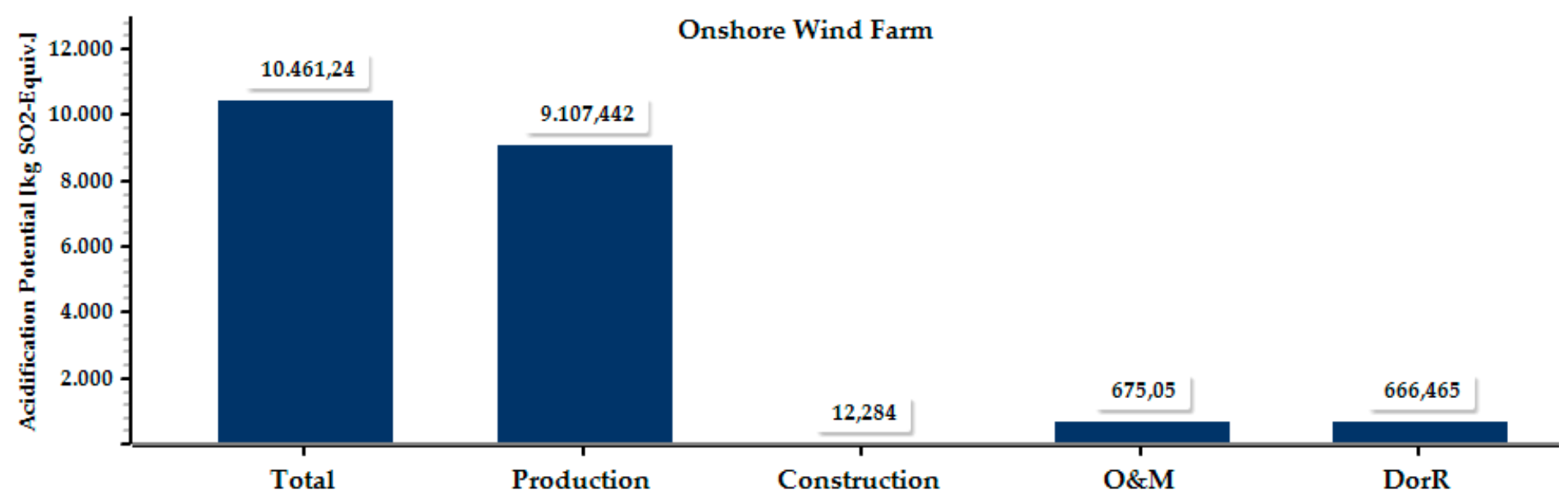

Figure 3. Acidification potential for the photovoltaic power plant with a real recycling plant case.

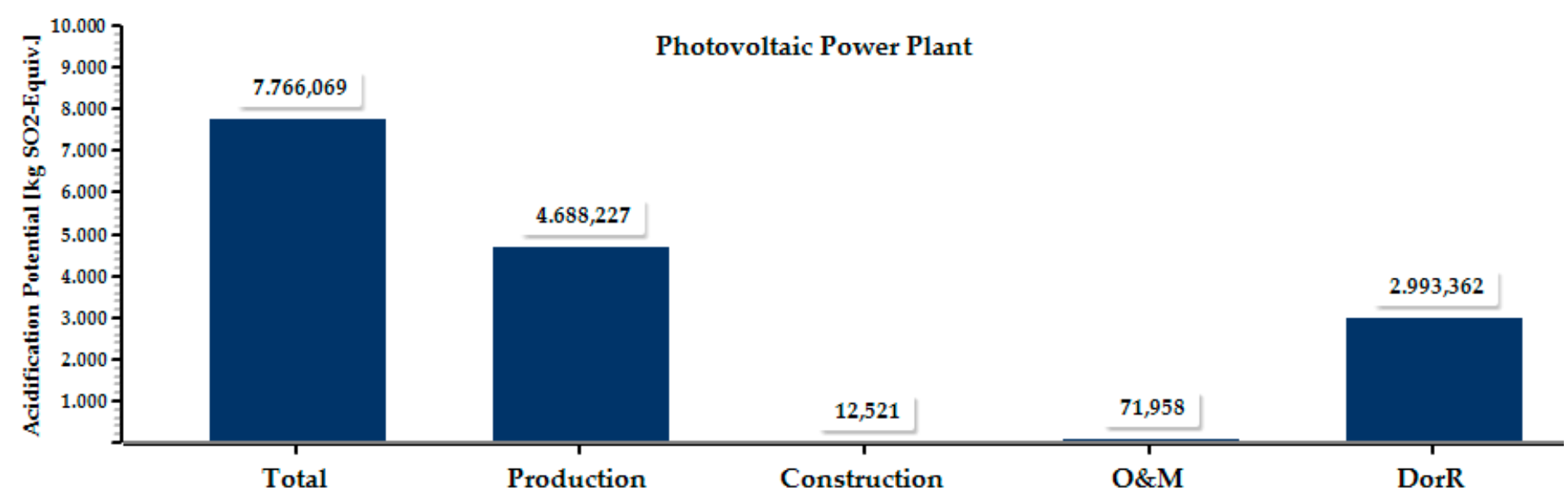

Figure 4. Acidification potential for the onshore wind farm. 


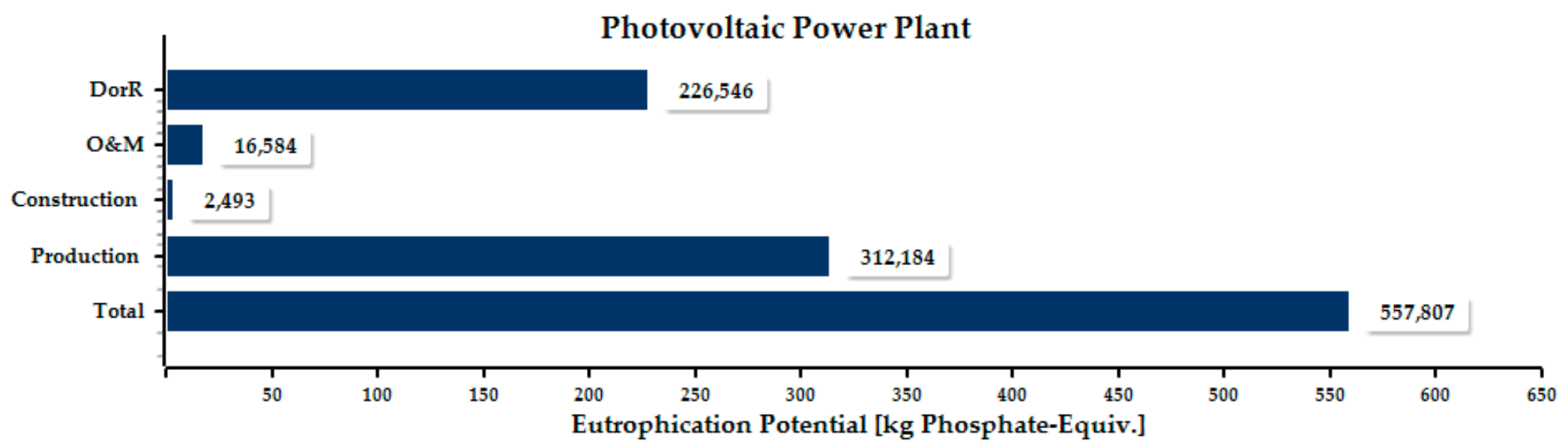

Figure 5. Eutrophication potential for the photovoltaic power plant with a real recycling plant case.

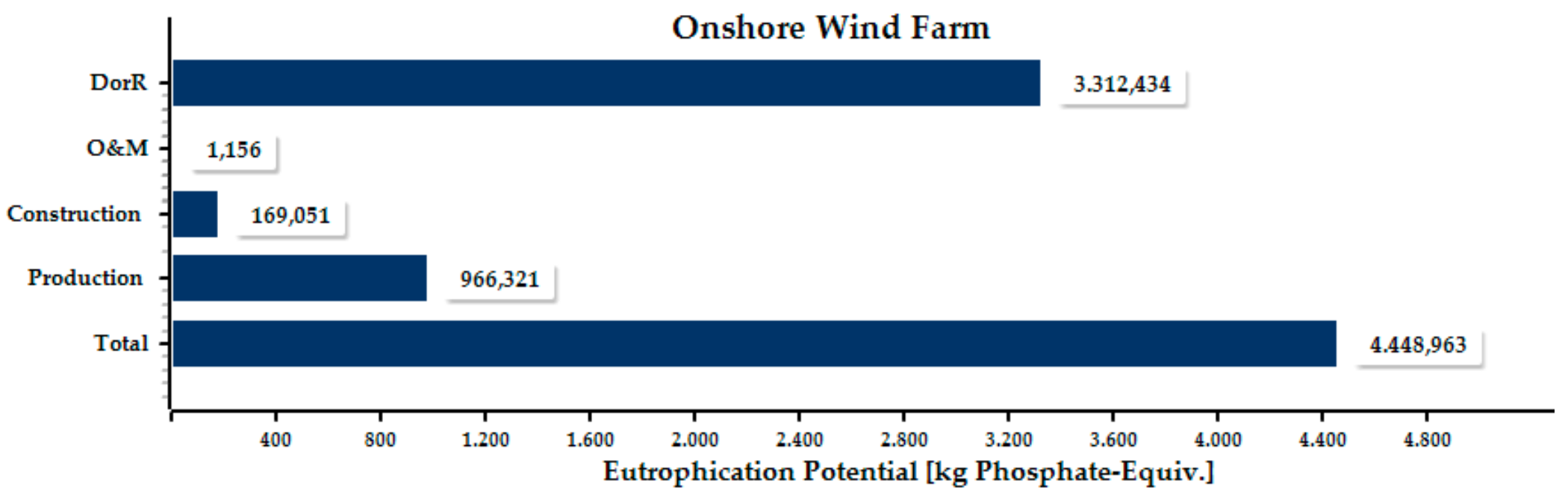

Figure 6. Eutrophication potential for the onshore wind farm. 


\section{Photovoltaic Power Plant}

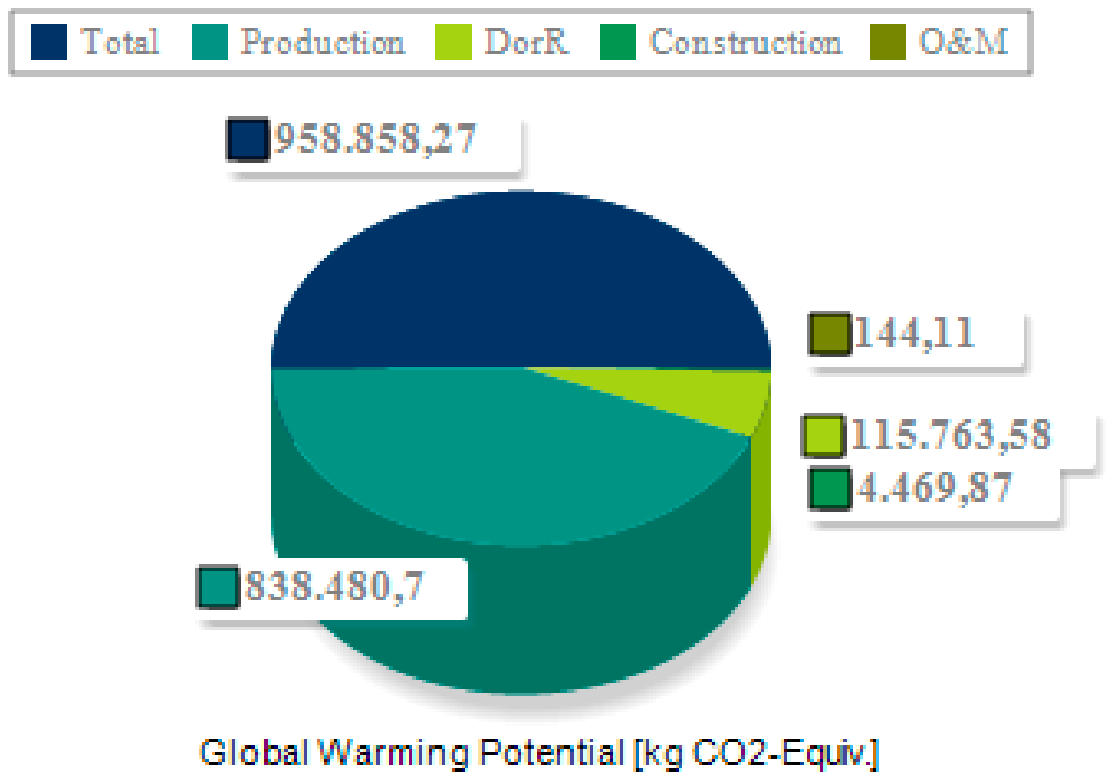

Figure 7. Global warming potential of photovoltaic power plant with real recycling plant case.

\section{Onshore Wind Farm}

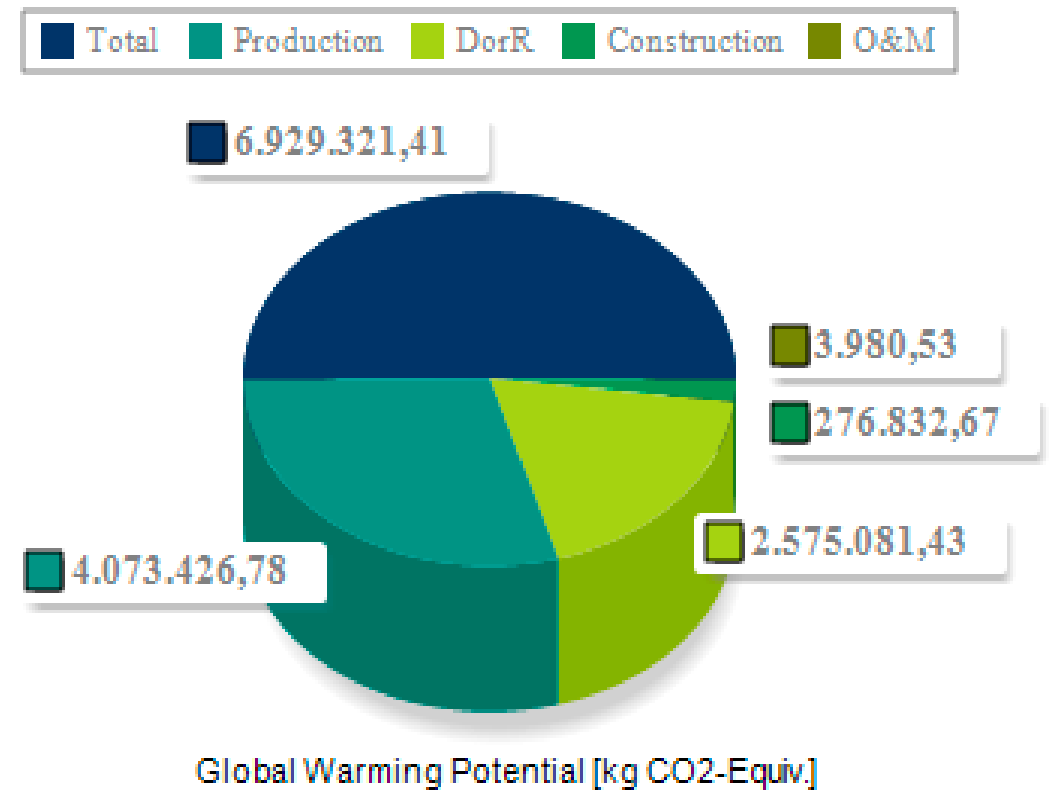

Figure 8. Global warming potential of onshore wind farm. 


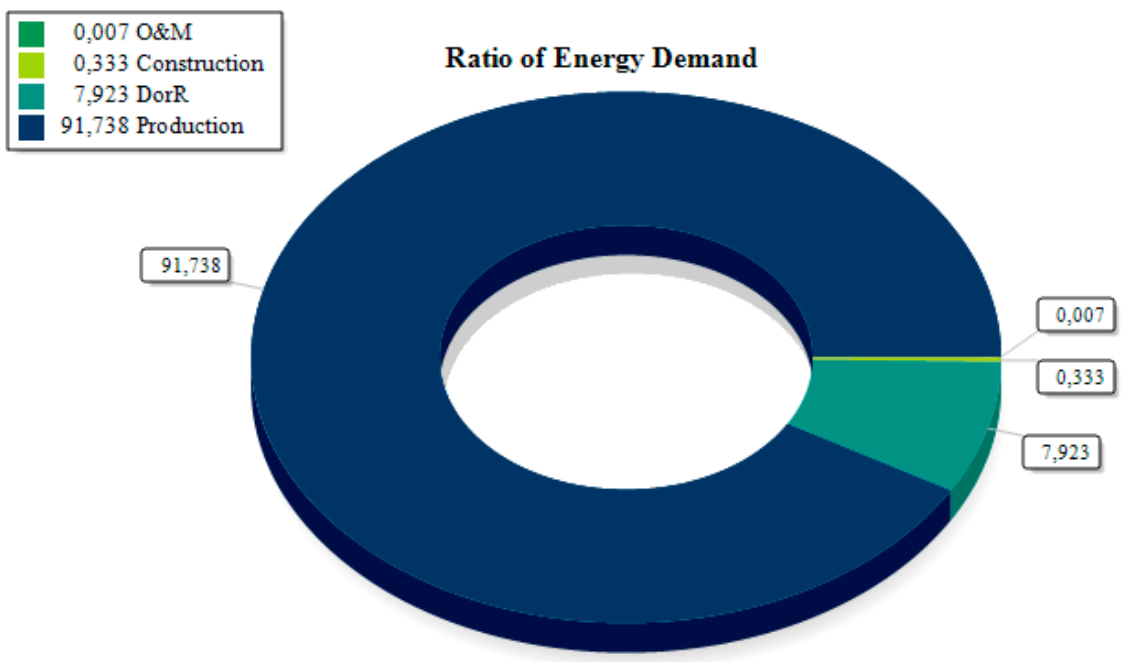

Photovoltaic Power Plant

Figure 9. Energy requirement ratios for the phases of the photovoltaic power plant.

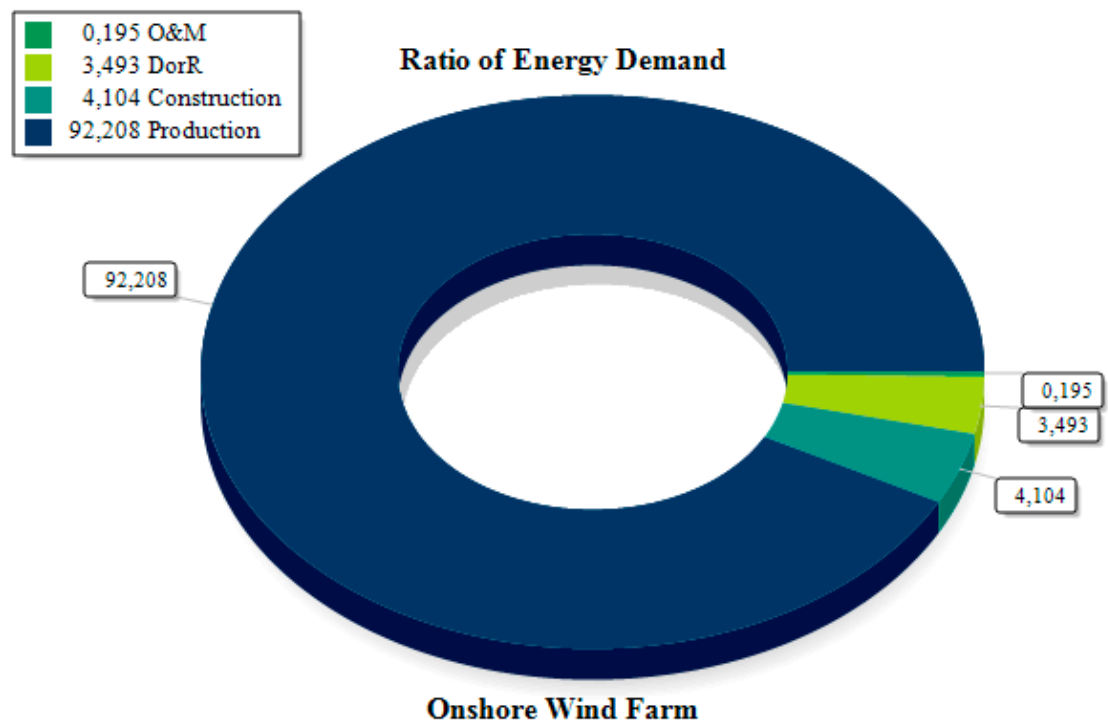

Figure 10. The energy requirement ratios for the phases of the onshore wind farm.

Table 10. Selected LCIA results.

\begin{tabular}{ccc}
\hline & Onshore Wind Farm & Photovoltaic Power Plant \\
\hline Global Warming Potential [kg CO $\mathbf{C O}_{2}$-eq./MWh] & 10.58 & 18.33 \\
Acidification Potential [kg SO -eq./MWh] $_{2}$ - & 0.01538 & 0.09816 \\
Eutrophication Potential [kg Phosphate-eq./MWh] & 0.00654 & 0.00794 \\
Energy Pay Back Time [year] & 0.62 & 2.06 \\
Cumulative Energy Demand [MJ/MWh] & 104.65 & 234.53 \\
\hline
\end{tabular}

\subsection{Life Cycle Cost Analysis (LCCA)}

The results of life cycle calculations based on the prices of 2019 are summarized in Table 11. As seen in Table 11, $\mathrm{LCC}_{\mathrm{ONW}}$ is $\$ 23,949,194.42$ and $\mathrm{LCC}_{\mathrm{PV}}$ is $\$ 2,826,759.22$. Ratios of transportation cost during the phases are shown in Table 11 for each configuration. The ratio of the transportation cost of the third phase for each system is equal to 1 since disposal or recycling phase costs for each configuration are based on the transportation costs from Equation (6) and Equation (11). The transportation costs are not crucial since the material costs for each phase are more dominant than the transportation costs for each 
case, as seen in Table 11. However, whether LCC is a useful tool or not for decision-making between distinct renewable configurations for a selected region, Bozcaada Island, cannot be understood from these cost results. Hence, levelized unit costs for producing $1 \mathrm{MWh}$ electricity are calculated to make a comparison. In other words, the required cost during their lifecycle is measured with a levelized unit cost to produce 1MWh electricity. The levelized unit cost for electricity is shown as LUCE in the rest of the study and Equation (12) shows its calculation methodology.

$$
\text { LUCE }=\frac{\text { Lifecycle cost of the system }[\$]}{\text { Expected electricty generation from the system }[\mathrm{MWh}]}
$$

Table 11. Life cycle costs of the configurations.

\begin{tabular}{ccccc}
\hline & \multicolumn{2}{c}{ Onshore Wind Farm } & \multicolumn{2}{c}{ Photovoltaic Power Plant } \\
\hline \multirow{2}{*}{ Cost specifications } & Total cost for & Ratios of & Total cost for & Ratios of \\
the phases [\$] & the transportation cost & the phases [\$] & the transportation cost \\
IIC & $23,838,415.88$ & 0.0043 & $2,104,369.07$ & 0.0006 \\
O and M & $106,961.61$ & 0.0016 & $713,648.20$ & 0.0023 \\
DorR & 3816.94 & 1 & 8741.95 & 1 \\
LCC & $23,949,194.42$ & 0.0044 & $2,826,759.22$ & 0.0041 \\
\hline
\end{tabular}

\subsection{Sensitivity Analysis}

Sensitivity analysis of each system are conducted separately for the photovoltaic power plant and the onshore wind farm.

\subsubsection{Sensitivity Analysis for the PV System}

Sensitivity analysis of the PV system include three cases. For the first and second case, recycling strategies of the photovoltaic power plant are changed, as seen in Table 12. A detailed description of recycling with the end of-life approach and real recycling plant case are conducted in the disposal or recycling phase of the photovoltaic system. In addition to this, the transportation distance for all scrap materials is indicated in Table 4 by a $300 \mathrm{~km}$ truck and an $8 \mathrm{~km}$ ferry. The difference between the second and the third case is applied for the recycling ratios for aluminum scraps in the open loop recycling. In the second case, the ratio is taken as 0.7 and 0.9 is the selected value for the third case. The results are also presented in Table 12.

Table 12. Sensitivity case specifications for the PV system.

\begin{tabular}{cccc}
\hline & \multicolumn{2}{c}{ Photovoltaic Power Plant } & \\
\hline Cases & First Case & Second Case (Base Case) & Third Case \\
Phase & Recycling with & Real recycling plant case & Real recycling plant case \\
& the end-of life approach & Aluminum recycling & Aluminum recycling \\
Differences & Without scrap materials & rotio $=0.9$ \\
GHGs [kg CO -eq./MWh] $_{\text {EPBT [years] }}^{\text {transportation }}$ & 16.07 & ratio $=0.7$ & 18.33 \\
CED [MJ/MWh] & 1.82 & 18.33 & 2.06 \\
\hline
\end{tabular}

The results of them are compared as the sensitivity analysis of the PV plant. The LCIA results for environmental characteristics of the recycling strategies are demonstrated in Figures 11 and 12 , respectively. 


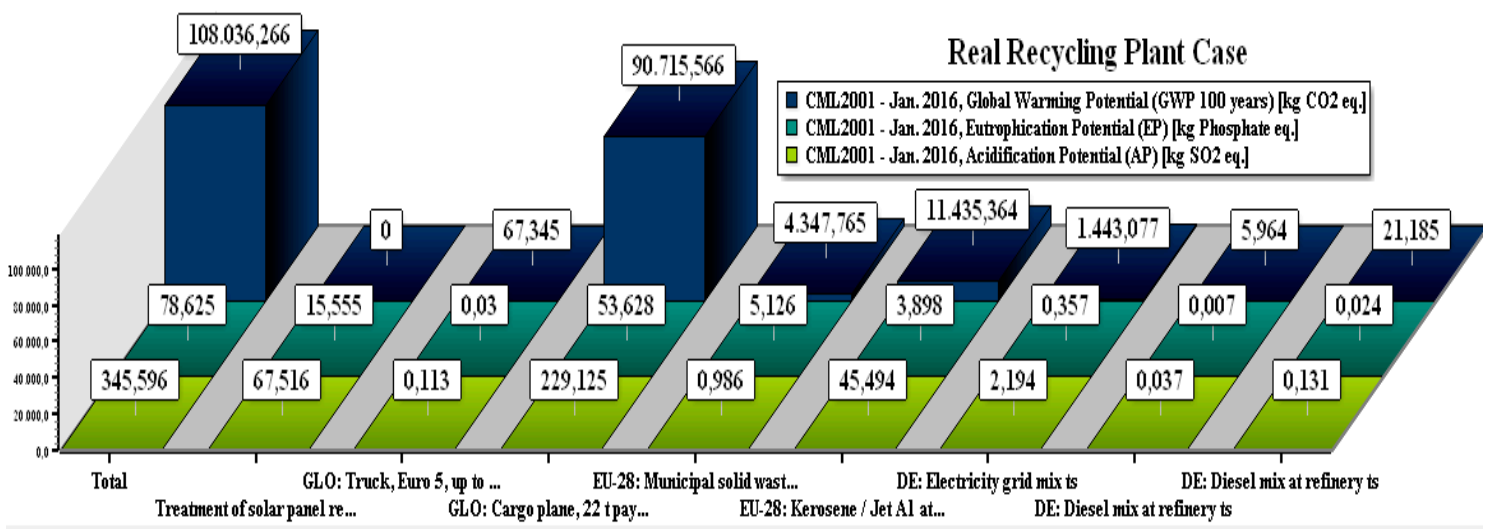

Figure 11. Quantities of recycling in a real recycling plant.

As seen in Figures 11 and 12, greenhouse gas emissions for the real recycling plant case are higher than greenhouse gas emissions for recycling with the end-of-life approach. The major reason is the difference between transportation distances in order to reach recycling plants. In this respect, with the recycling with end-of-life approach, which is based on glass recycling, is more meaningful for the recycling of the photovoltaic power plant system. Recycling of glass from solar panels in İzmir prevents greenhouse gas emission required to produce glass from sand.

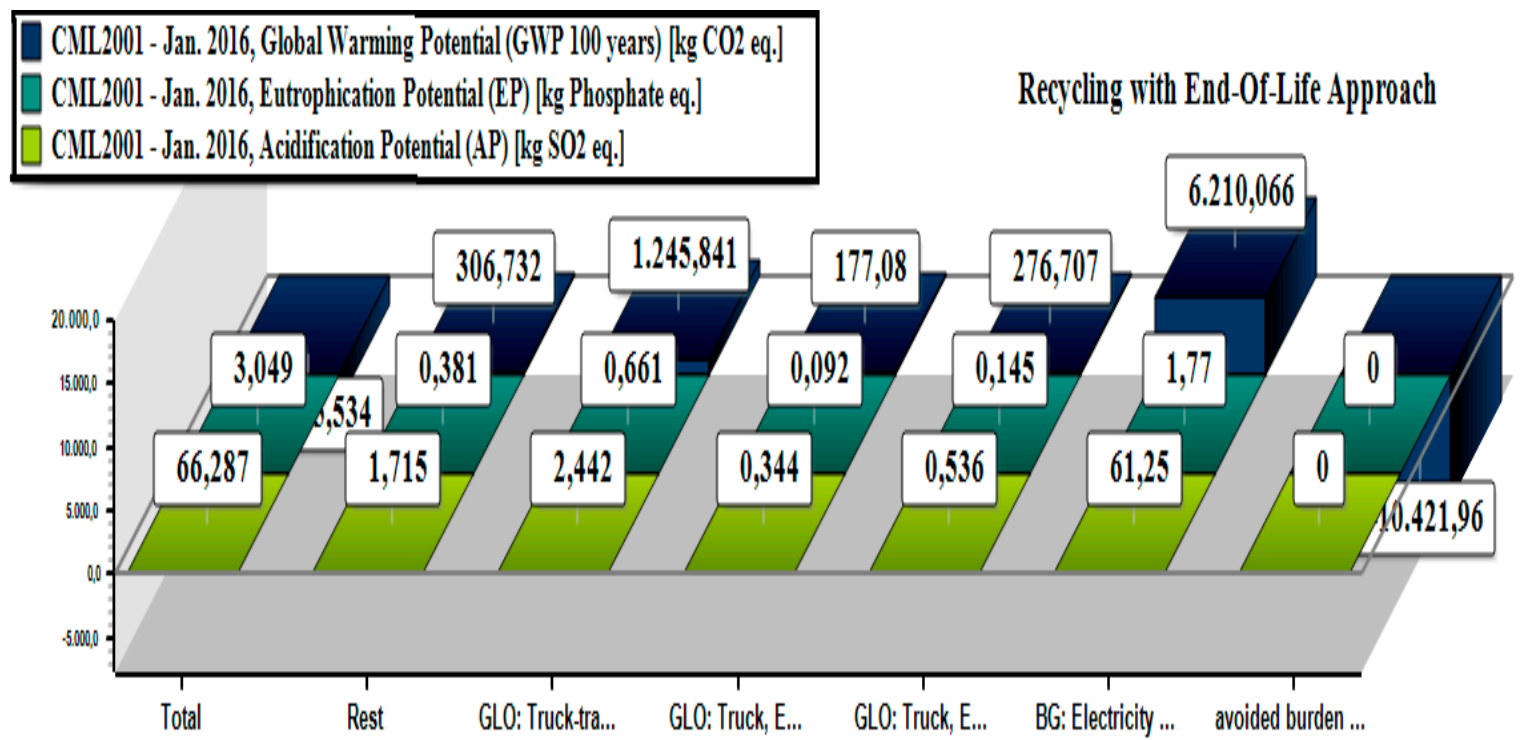

Figure 12. Environmental quantities of recycling with end-of-life approach.

\subsubsection{Sensitivity Analysis for Wind Farm}

In the case of the wind farm, scraps containing iron from the decompositions of nacelle and tower, composite from the decomposition of rotor blades, and aluminum from the decomposition of cables and inverters, are focused materials for the sensitivity analysis of the onshore wind farm. Sensitivity analyses are divided into two parts and named as Case A and Case B. Transfer procedures of scrap materials to the distribution center are excluded from the life cycle analysis of the wind plant in Case A. In other words, open loop recycling is applied to scrap materials without considering transportations of them for Case A. On the other hand, scrap materials are transferred to the distribution center for the application of open loop recycling procedure by a $15 \mathrm{~km}$ ferry and a $100 \mathrm{~km}$ truck in the second option of sensitivity analysis of the wind plant and it is called Case B, as summarized in Table 13. Results of the cases are also demonstrated in the table. 
Transfer procedure of scrap materials to the distribution center increased global warming potential, energy pay-back time of the plant, and cumulative energy demand as expected. However, a difference between the cases are not significant. For example, transportation of scrap materials causes $1.6 \%$ (approximately four days) increase in the energy pay-back time for the onshore wind farm. As concrete from foundations and tower are left in the construction site for future investments, other scraps, which are iron, aluminum, and composite, should be transferred the distribution center for a cleaner environment after disposal of the plant.

Table 13. Sensitivity case specifications for the wind farm.

\begin{tabular}{ccc}
\hline & Onshore Wind Farm & \\
\hline Cases & Case A & Case B (Base case) \\
Phase & Disposal or recycling & Disposal or recycling \\
Differences & without scrap materials transportation & with scrap materials transportation \\
& 100 km by truck and 15 km by ferry) \\
GHGs [kg CO ${ }_{2}$ eq./MWh] & 0.67 & 10.58 \\
EPBT [years] & 104.46 & 0.62 \\
CED [MJ/MWh] & 104.65 \\
\hline
\end{tabular}

\section{Discussion}

In this section, results presented in Section 5 are evaluated for two distinct renewable systems.

It can be seen in Figures 3 and 4 that a total acidification potential of the PV system and total acidification potential of the onshore wind farm throughout the lifecycle are higher than the photovoltaic power plant.

Acidification potential of the onshore wind farm is $523.1 \mathrm{~kg} \mathrm{SO}_{2}$-eq./year while acidification potential of the photovoltaic power plant is $171.2 \mathrm{~kg} \mathrm{SO}$-eq./year, annually. However, acidification potential of the onshore wind farm is lower than the photovoltaic power plant in terms of levelized characteristics, which are found by dividing with a functional unit of LCA and are shown in Table 10. As a result, the photovoltaic power plant is less advantageous than the onshore wind farm in terms of acidification potential.

Although eutrophication potential of the wind farm, which is annually $222.4 \mathrm{~kg}$ phosphate-eq./year, is higher than the eutrophication potential of the photovoltaic power plant, which is annually $13.8 \mathrm{~kg}$ phosphate-eq./year. The onshore wind farm shows a better trend than the photovoltaic power plant in terms of levelized characteristics of eutrophication potential based on a functional unit, as indicated in Table 10, in the case of eutrophication potential throughout life cycle analyses of different technologies.

In the case of energy pay-back time, photovoltaic technology requires approximately 25 months to produce primary energy which is initially embedded, whereas the onshore wind farm needs 7.5 months. It can be explained by the primary energy requirements of each technology and the power production capacity for the technologies. The energy requirement of production technologies can be clarified by a cumulative energy demand. As seen in Table 10, cumulative energy requirement of onshore wind farm is less than cumulative energy demand of photovoltaic power plant to be invested in Bozcaada. Onshore wind farm with $34 \mathrm{GWh}$ average annual electricity production has higher potential than photovoltaic power plant in terms of power production capacity on the selected area which is approximately the same for both technologies.

When annual greenhouse gas emissions of both configurations are examined, onshore wind farm emits $359,739.0 \mathrm{~kg} \mathrm{CO}$-eq. per a year and $\mathrm{PV}$ system emits $31,961.9 \mathrm{~kg} \mathrm{CO}_{2}$-eq. per a year. However, onshore wind farm emits less greenhouse gases than photovoltaic power plant to produce $1 \mathrm{MWh}$ electricity as seen in Table 10 by means of levelized characteristics of global warming potential.

Figures 9 and 10 indicate that operation and maintenance phase shows the least primary energy demand for both renewable systems as expected. Production phase leads to the highest value of greenhouse gas emissions not only for onshore wind farm but also for photovoltaic power plant. Decommissioning and recycling phase is the second most energy required phases for both technologies. 
The construction phase of power plant demonstrates a lower ratio than the construction phase of onshore wind farm as expected since there is no requirement of utilization of construction machines in order to establish a power plant unlike in the case of the establishment of wind farm. Moreover, the construction of infrastructure is simpler for the power plant than the onshore wind farm.

In terms of levelized unit cost to produce $1 \mathrm{MWh}$ electricity, onshore wind farm is more logical investment than photovoltaic technology for Bozcaada Island although the initial investment cost of onshore wind plant configuration is approximately 11 times of the initial investment cost of photovoltaic power plant configurations. When the life cycle costs of both technologies are considered, transportation costs of the material are insignificant not only PV system but also onshore wind farm as seen Table 11. However, the transportation cost in initial investment is higher for onshore wind farm than photovoltaic technology due the fact that the total weight of wind turbines is higher than the weight of solar panels.

In the case of sensitivity analysis of PV plant, the increase in the recycling ratio for aluminum scraps leads to $0.02 \%$ change in the cumulative energy demand, change in the EPBT and GWP are insignificant as seen Table 12 while change in the recycling strategies causes approximately $11.7 \%$ decrease in the global warming potential. In terms of environment, recycling with end-of life approach is more logical for the PV plant. For the sensitivity analysis of wind farm, the changes between Case $A$ and Case $B$ are insignificant.

As seen in Table 14, phases up to disposal or recycling phases of each technology require less energy and less costs than the entire life cycles of each configurations as expected. In fact, the levelized unit cost of electricity should be lower with open loop recycling procedure in the real life. In other words, in real life, it should be less than the costs calculated in this study when scraps are sold. However, it can be utilized for the comparison between the systems. In addition to this, operation and maintenance procedure of the PV system is approximately $25 \%$ of total cost of photovoltaic power plant due to mainly replacement of inverters even though it is almost insignificant for the case of onshore wind farm disposal or recycling cost is less dominant in the case of wind technology than in the PV system. It can be explained by both developed recycling in the wind sector and large amount of landfill treatment which has no cost.

Table 14. Results for the different life cycle boundaries.

\begin{tabular}{cccccc}
\hline $\begin{array}{c}\text { Phases } \\
\text { Results }\end{array}$ & Production & Construction & O\&M & DorR & System \\
\hline \multirow{2}{*}{ GHGs [kg CO -eq./MWh] } & 16.0291 & 0.0854 & 0.0028 & 2.2130 & PV \\
& 6.0102 & 0.4077 & 0.0059 & 4.1567 & Onshore \\
\hline \multirow{2}{*}{ EPBT [years] } & 1.7881 & 0.0102 & 0.0002 & 0.2649 & PV \\
& 0.5562 & 0.0347 & 0.0016 & 0.0229 & Onshore \\
\hline \multirow{2}{*}{ CED [MJ/MWh] } & 203.7367 & 1.1390 & 0.0249 & 29.6316 & PV \\
& 94.7149 & 5.8463 & 0.2716 & 3.8147 & Onshore \\
\hline \multirow{2}{*}{ LUCE [\$/MWh] } & \multicolumn{2}{c}{40.2288} & 13.6427 & 0.1671 & PV \\
& \multicolumn{2}{c}{35.0565} & 0.1573 & 0.0056 & Onshore \\
\hline
\end{tabular}

The production phase of both configurations requires extensive energy than other phases. Although the PV system causes enormous GHGs in the production phase, both production and disposal or the recycling phase are the main cause in the wind energy. It can be said that both configurations lead to almost zero global warming potential during their operation.

In terms of energy pay-back time, recycling of the wind farm is more efficient than recycling of the photovoltaic power plant. Furthermore, the disposal or recycling phase of the onshore wind farm requires less primary energy than disposal or recycling phase of the PV system by means of the comparison between the values of cumulative energy demand in Table 14 found. However, disposal or the recycling procedure of onshore wind farm leads to higher greenhouse 
emissions than the procedure of disposal or recycling for the photovoltaic power plant. It can be explained that recycling strategies of wind farm is cleaner than the photovoltaic power plant in terms of process chain in the production phase of wind turbine.

In the case of the life cycle cost calculations, LUCE $\mathrm{ONW}_{1}, 35.2194 \$ / \mathrm{MWh}$, and LUCE $\mathrm{PV}_{\text {, }}$ $54.0386 \$ / \mathrm{MWh}$ are validated. The costs calculated in this study is lower than costs in Reference [34], as expected, because the main assumption of this study was not including insurance costs, labor costs and project costs.

\section{Conclusions}

This paper investigated the environmental and economic impacts of two renewable energy systems for a selected region, which is Bozcaada Island. Our findings indicate that the onshore wind farm is more appropriate for the selected region. All of the environmental specifications show a better trend for the onshore wind farm than the photovoltaic power plant. In terms of costs, establishment of wind farm is more meaningful for the generation of electricity than the establishment of the PV system even though annual parameters of global warming potential indicate that the onshore wind farm emits more greenhouse emissions than the land-based photovoltaic plant. In other words, the wind farm is cleaner to generate $1 \mathrm{MWh}$ electricity than PV technology when the lifespans of systems are considered in terms of selected environmental quantities. In the comparison of levelized unit cost, the onshore wind farm is more economic than the PV system for Bozcaada Island to generate electricity. This study shows that the LCA and LCCA of wind and solar energy systems will contribute to investment decision-making by considering environmental impacts and economic analysis.

This study indicates that LCA and LCCA should be used to determine the most feasible option for a selected region (i.e., Bozcaada Island), which has many renewable energy potentials like wind and solar. As is mentioned in Section 1, Bozcaada Island has $308.0 \mathrm{cal} / \mathrm{cm}^{2}$ sunshine radiation per day and 7.5 hours sunshine duration per day, as well as wind energy potential with $8.4 \mathrm{~m} / \mathrm{s}$ average wind speed at $50 \mathrm{~m}$ [24].

During this study, the life spans of the proposed the PV system and existing wind farm are considered like in the other studies suggested for each system. In other words, the life of the photovoltaic power plant is accepted 30 years and the useful life of the existing wind farm is determined to be 20 years. However, there is a still a requirement to investigate about real lifespans of the systems by means of the sensitivity analysis including either change of the life spans or a fixed economic life. Issues like risk have a significant importance for solar panel system applications as well as wind turbines. Therefore, a future study should also include life cycle impacts of risks to determine a more comprehensive LCA study for evaluating renewable energy systems.

Decommissioning and the recycling phase with the current technology causes enormous greenhouse gas emissions not only in PV plant configurations but also the onshore wind farm. The main reasons can be decommissioning and disposal of the plant as well as the transportation of waste and recycling materials. Undeveloped recycling technologies especially in the case of photovoltaic power plant can be another reason for the extensive global warming potential of the fourth phase of photovoltaic technology. There is an urgent requirement of recycling strategies of solar panels.

In the case of land-based photovoltaic technology, selection of system boundaries affects results significantly. For example, up to the disposal and recycling phase, the PV system emits $16.12 \mathrm{~kg}$ $\mathrm{CO}_{2}$-eq. for the generation of $1 \mathrm{MWh}$ electricity. The disposal and recycling phase of the PV plant leads to approximately $13.7 \%$ increase in the greenhouse emissions, according to the boundaries defined as from the production to the disposal phase. However, disposal and recycling of the onshore wind farm causes almost a $65 \%$ increase in GWP, according to its assessment from production to the disposal phase. With the aid of EPBT and CED in Table 14, the reason a 65\% increase for the wind plant can be claimed as landfill processes for concrete and composite materials since there is no significant increase in energy requirements which is required for the transportation of waste materials for the fourth stage of the wind farm. For the photovoltaic power plant, its fourth phase needs extensive primary energy. 
This can be related with utilization of cargo plane for the transfer of solar panels waste since there is no other energy embedded procedure during the modelling part of the fourth phase of the photovoltaic power plant. As mentioned in fourth phase of the PV system in Section 3.2, recycling of solar panels investigations including energy flows are not well-defined in the literature so far. It can be suggested that recycling technologies of the PV system should be improved in the near future.

Results of this study indicate that wind farm is cleaner than photovoltaic power plant in terms of greenhouse gas emission, acidification potential and eutrophication potential for Bozcaada island similar to Canadian case study without the adoption procedure which includes normalization, weighting and single score [45]. It is critical to be able to determine whether the wind system is cleaner than PV system for any location. However, there is still a need to carry out further research to demonstrate cleanness of wind technology compared to photovoltaic technology.

Author Contributions: The authors contributed equally to this paper.

Funding: This research received no external funding.

Acknowledgments: It should be reported that short part of this paper will be presented at 18th International Congress of the International Maritime Association of the Mediterranean in 2019.

Conflicts of Interest: The authors declare no conflict of interest.

\section{Nomenclature}

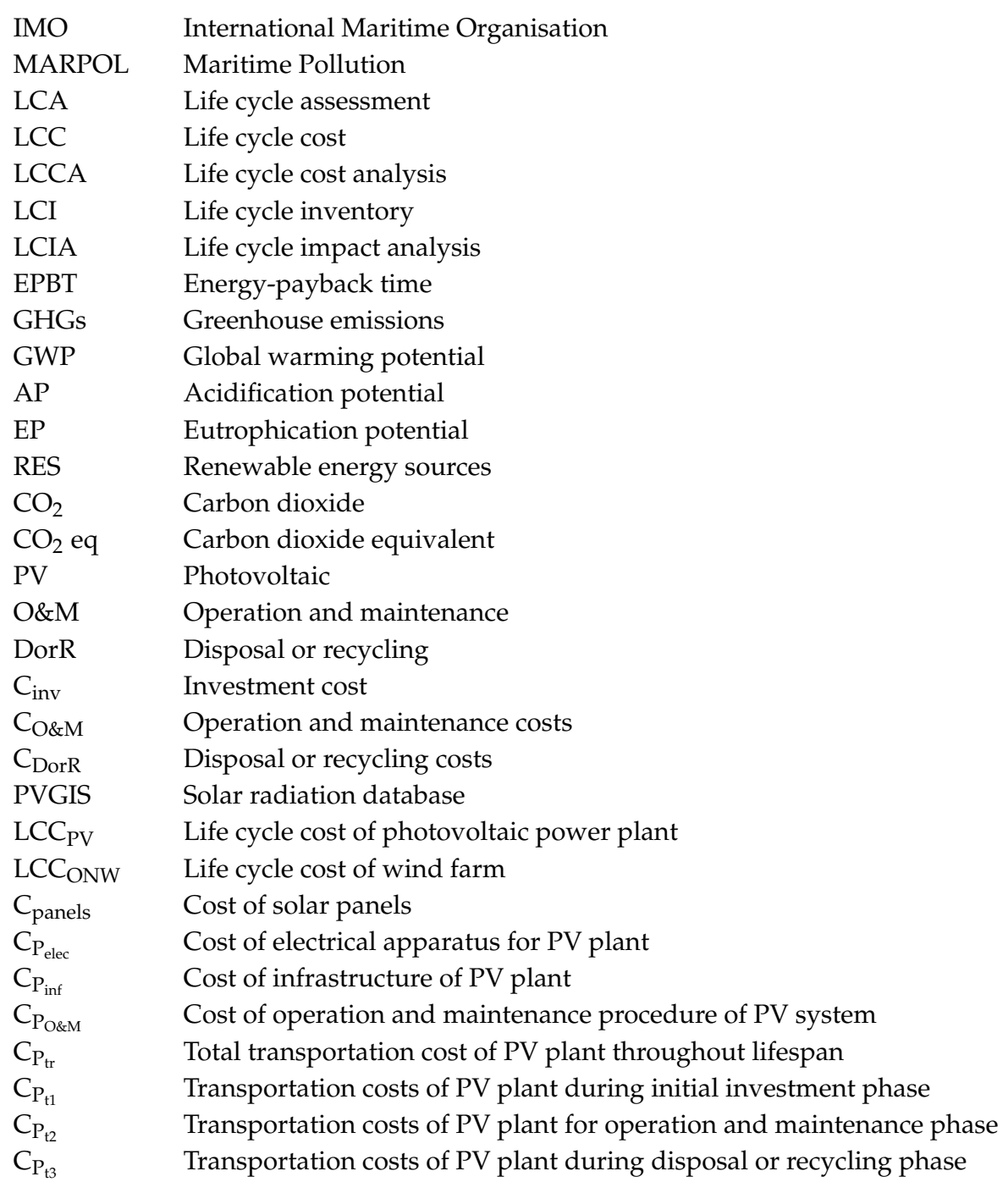




$\begin{array}{ll}C_{\text {tap water }} & \text { Cost of tap water } \\ C_{\text {spare panels }} & \text { Cost of spare solar panels } \\ C_{P_{\text {DorR }}} & \text { Cost of disposal or recycling of photovoltaic power plant } \\ \text { BP } & \text { British Petrol } \\ C_{\text {turbines }} & \text { Cost of turbines } \\ C_{W_{\text {elec }}} & \text { Cost of electrical apparatus for wind farm } \\ C_{W_{\text {inf }}} & \text { Cost of infrastructure of wind farm } \\ C_{W_{\text {O\&M }}} & \text { Cost of operation and maintenance procedure of wind farm } \\ C_{W_{\text {tr }}} & \text { Total transportation cost of wind farm throughout lifespan } \\ C_{W_{t 1}} & \text { Transportation costs of wind farm during initial investment phase } \\ C_{W_{t 2}} & \text { Transportation costs of wind farm for operation and maintenance phase } \\ C_{W_{t 3}} & \text { Transportation costs of wind farm during disposal or recycling phase } \\ C_{W_{M}} & \text { Cost of maintenance procedure of wind farm in terms of material costs } \\ C_{W_{\text {DorR }}} & \text { Cost of disposal or recycling of wind farm } \\ \text { OECD } & \text { Organization for Economic Co-operation and Development } \\ \text { IIC } & \text { Initial investment cost } \\ \text { LUCE } & \text { Levelized unit cost to produce } 1 \text { MWh electricity } \\ \text { LUCE } & \text { Levelized unit cost to produce } 1 \text { MWh electricity for wind farm } \\ \text { LUCE } & \text { Levelized unit cost to produce } 1 \text { MWh electricity for photovoltaic power plant }\end{array}$

\section{References}

1. Schanes, K.; Giljum, S.; Hertwich, E. Low carbon lifestyles: A framework to structure consumption strategies and options to reduce carbon footprints. J. Clean. Prod. 2016, 139, 1033-1043. [CrossRef]

2. Kavli, H.P.; Oguz, E.; Tezdogan, T. A comparative study on the design of an environmentally friendly RoPax ferry using CFD. Ocean. Eng. 2017, 137, 22-37. [CrossRef]

3. European Union. Energy Road Map 2050; Publications Office of the European Union: Brussels, Belgium, 2012.

4. Jeong, B.; Oğuz, E.; Wang, H.; Zhou, P. Multi-criteria decision-making for marine propulsion: Hybrid, diesel electric and diesel mechanical systems from cost-environment-risk perspectives. Appl. Energy 2018, 230, 1065-1081. [CrossRef]

5. Aysar, M.; Lorenzo, S.; Ponci, F.; Monti, A. Multi-agent based intelligent frequency control in multi-terminal dc grid-based hybrid ac/dc networks. IET Renew. Power Gener. 2018, 12, 1434-1443.

6. Adrees, A.; Milanovic, J.V.; Mancarella, P. The Influence of Location of Distributed Energy Storage Systems on Primary Frequency Response of Low Inertia Power Systems. In Proceedings of the IEEE Power \& Energy Society General Meeting (PESGM), Portland, OR, USA, 5-10 August 2018.

7. Wang, H.; Oguz, E.; Jeong, B.; Zhou, P. Life cycle cost and environmental impact analysis of ship hull maintenance strategies for a short route hybrid ferry. Ocean. Eng. 2018, 161, 20-28. [CrossRef]

8. Marzi, J.; Papanikolaou, A.; Corrignan, P.; Zaraphonitisc, G.; Harries, S. HOLISTIC Ship Design for Future Waterborne Transport. In Proceedings of the 7th Transport Research Arena TRA 2018, Austria, Vienna, 16-19 April 2018.

9. Jeong, B.; Wang, H.; Oguz, E.; Zhou, P. An effective framework for life cycle and cost assesment for marine vessels aiming to select optimal propulsion systems. J. Clean. Prod. 2018, 187, 111-130. [CrossRef]

10. Wang, H.; Oguz, E.; Jeong, B.; Zhou, P. Life cycle and economic assesment pf solar panel array applied to a short route ferry. J. Clean. Prod. 2019, 219, 471-484. [CrossRef]

11. Hernández, C.V.; González, J.S.; Blanco, R.F. New method to assess the long-term role of wind energy generation in reduction of $\mathrm{CO}_{2}$ emissions- Case Study of european Union. J. Clean. Prod. 2019, 207, 1099-1111. [CrossRef]

12. Özkale, C.; Celik, C.; Turkmen, A.C.; Cakmaz, E.S. Decision analysis application intended for selection of a power plant running on renewable energy sources. Renew. Sustain. Energy Rev. 2017, 70, 1011-1021. [CrossRef]

13. Santoyo-Castelazo, E.; Azapagic, A. Sustainability assessment of energy systems: Integrating environmental, economic and social aspects. J. Clean. Prod. 2014, 80, 119-138. [CrossRef]

14. Hong, J.H.; Kim, J.; Son, W.; Shin, H.; Kim, N.; Lee, W.K.; Kim, J. Long-term energy strategy scenarios for South Korea: Transition to a sustainable energy system. Energy Policy 2019, 127, 425-437. [CrossRef] 
15. Keleş, S.; Bilgen, S. Renewable energy sources in Turkey for climate change mitigation and energy sustainability. Renew. Sustain. Energy Rev. 2012, 16, 5199-5206. [CrossRef]

16. Panwar, N.; Kaushik, S.; Kothari, S. Role of renewable energy sources in environmental protection: A review. Renew. Sustain. Energy Rev. 2011, 15, 1513-1524. [CrossRef]

17. Li, Q.S.; Chen, F.; Li, Y.; Lee, Y. Implementing wind turbines in a tall building for power generation: A study of wind loads and wind speed amplifications. J. Wind Eng. Ind. Aerodyn. 2013, 116, 70-82. [CrossRef]

18. Vourdoubas, J. Review of sustainable energy technologies used in buildings in the Mediterranean basin. J. Build. Sustain. 2018, 1, 2.

19. Yuan, X.; Wang, X.; Zuo, J. Renewable energy in buildings in China-A review. Renew. Sustain. Energy Rev. 2013, 24, 1-8. [CrossRef]

20. IPEEC Building Energy Efficiency Taskgroup. Zero Energy Building Definitions and Policy Activity-An International Review; International Partnership for Energy Efficiency Cooperation: Paris, France, 2018.

21. Eremia, M.; Toma, L.; Sanduleac, M. The Smart City Concept in the 21st century. Procedia Eng. 2017, 181, 12-19. [CrossRef]

22. Nistor, S.; Carr, S.; Sooriyabandara, M. The Island Hydrogen Project: Electrolytic Generated Hydrogen for Automotive and Maritime Applications. IEEE Electrif. Mag. 2018, 6, 55-60. [CrossRef]

23. Yazici, M.S.; Hatipoğlu, M. Hydrogen and fuel cell demonstrations in Turkey. Energy Procedia 2012, 29, 683-689. [CrossRef]

24. Oğulata, R.T. Energy sector and wind energy potential in Turkey. Renew. Sustain. Energy Rev. 2003, 7, 469-484. [CrossRef]

25. Jackson, D.; Brander, M. The risk of burden shifting from embodied carbon calculation tools for the infrastructure sector. J. Clean. Prod. 2019, 223, 739-746. [CrossRef]

26. Akanbi, L.A.; Oyedele, L.O.; Omoteso, K.; Bilal, M.; Akinade, O.O.; Ajayi, A.O.; Delgado, J.M.D.; Owolabi, H.A. Disassembly and deconstruction analytics system (D-DAS) for construction in a circular economy. J. Clean. Prod. 2019, 223, 386-396. [CrossRef]

27. Wiedemann, S.; McGahan, E.; Murphy, C.; Yan, M.-J.; Henry, B.; Thoma, G.; Ledgard, S. Enviromental impacts and resource use of Australian beef and lamb exported to the USA determined using life cycle assessment. J. Clean. Prod. 2015, 94, 67-75. [CrossRef]

28. Atilgan, B.; Azapagic, A. Life cycle enviromental impacts of electricity from fossil fuels in Turkey. J. Clean. Prod. 2014, 106, 555-564. [CrossRef]

29. Atilgan, B.; Azapagic, A. Renewable electricity in Turkey: Life cycle enviromental impacts. Renew. Energy 2016, 89, 649-657. [CrossRef]

30. Rakotoson, V.; Praene, J.P. A life cycle assessment approach to the electricity generation of French overseas territories. J. Clean. Prod. 2017, 168, 755-763. [CrossRef]

31. Utne, I.B. Life cycle cost (LCC) as a tool for improving sustainability in Norvewgian fishing fleet. J. Clean. Prod. 2009, 17, 335-344. [CrossRef]

32. Delugo, M.; Zanchi, L.; Maltese, S.; Bonoli, A.; Pierini, M. Enviromental and economic life cycle assessment of a lightweight solution for an automotive component: A comparison between talc-filled and hollow glass microspheres-reinforced polymer composites. J. Clean. Prod. 2016, 139, 548-560. [CrossRef]

33. Cheung, W.M.; Marsh, R.; Griffin, P.W.; Griffin, P.W.; Newnes, L.B.; Mileham, A.R.; Lanham, J.D. Towards cleaner production: A roadmap for predicting product end-of-life costs at early design concept. J. Clean. Prod. 2015, 87, 431-441. [CrossRef]

34. Yilan, G. Comparison of Life Cycle Assessment of Electricty Production Mix in Turkey with Future Electricty Production Scenarios; Marmara University Institute for Graduate Studies in Pure and Applied Sciences: Istanbul, Turkey, 2018.

35. Ormazabal, M.; Jaca, C.; Puga-Leal, R. Analysis and Comparison of Life Cycle Assessment and Carbon Footprint Software. Adv. Intell. Syst. Comput. 2014, 281, 1521-1530.

36. Speck, R.; Selke, S.; Auras, R.; Fitzsimmons, J. Choice of Life Cycle Assessment Software Can Impact Packaging System Decisions. Packag. Technol. Sci. 2015, 28, 579-588. [CrossRef]

37. Speck, R.; Selke, S.; Auras, R.; Fitzsimmons, J. Life Cycle Assessment Software: Selection Can Impact Results. J. Ind. Ecol. 2016, 20, 18-28. [CrossRef]

38. Herrmann, I.T.; Moltesen, A. Does it matter which Life Cycle Assessment (LCA) tool you choose? A comparative assessment of SimaPro and GaBi. J. Clean. Prod. 2015, 86, 163-169. [CrossRef] 
39. Silva, D.; Nunes, A.O.; da Silva Moris, A.; Moro, C.; Piekarski, T.O.R. How Important Is the LCA Software Tool You Choose Comparative Results from GaBi; openLCA, SimaPro and Umberto: Medellin, DC, USA, 2017.

40. Fu, Y.; Liu, X.; Yuan, Z. Life-cycle assessment of multi-crystalline photovoltaic (PV) systems in China. J. Clean. Prod. 2015, 86, 180-190. [CrossRef]

41. Nugent, D.; Sovacool, B.K. Assessing the lifecycle greenhouse gas emissions from solar PV and wind energy: A critical meta-survey. Energy Policy 2014, 65, 229-244. [CrossRef]

42. Bonou, A.; Laurent, A.; Olsen, S.I. Life cycle assessment of onshore and offshore wind energy-From theory to application. Appl. Energy 2016, 180, 327-337. [CrossRef]

43. Chipindula, J.; Botlaguduru, V.S.V.; Du, H.; Kommalapati, R.R.; Huque, Z. Life Cycle Environmental Impact of Onshore and Offshore Wind Farms in Texas. Sustainability 2018, 10, 2022. [CrossRef]

44. Haapala, K.R.; Prempreeda, P. Comparative life cycle assessment of 2.0 MW wind turbines. Int. J. Sustain. Manuf. 2014, 3, 170-185. [CrossRef]

45. Schmidt, K.; Alvarez, L.; Arevalo, J.; Abbassi, B. Life Cycle Impact Assessment of Renewable Energy Systems: Wind vs. Photovoltaic Systems. Int. J. Curr. Res. 2017, 9, 59140-59147.

46. Yudha, H.M.; Dewi, T.; Risma, P.; Oktarina, Y. Life Cycle Analysis for the Feasibility of Photovoltaic System Application in Indonesia. IOP Conf. Ser. Earth Environ. Sci. 2018, 124, 012005. [CrossRef]

47. Desideri, U.; Proietti, S.; Zepparelli, F.; Sdringola, P.; Bini, S. Life Cycle Assessment of a ground-mounted $1778 \mathrm{kWp}$ photovoltaic plant and comparison with traditional energy production systems. Appl. Energy 2012, 97, 930-943. [CrossRef]

48. Ito, M.; Kato, K.; Sugihara, H.; Kichimi, T.; Song, J.; Kurokawa, K. A Preliminary Study on Potential for Very Large-Scale Photovoltaic Power Generation (VLS-PV) System on the Gobi Desert from Economic and Environmental Viewpoints. Sol. Energy Mater. Sol. Cells 2003, 75, 507-517. [CrossRef]

49. Luo, W.; Khoo, Y.S.; Kumar, A.; Low, J.S.C.; Li, Y.; Tan, Y.S.; Wang, Y.; Aberle, A.G.; Ramakrishna, S. A comparative life-cycle assessment of photovoltaic electricity generation in Singapore by multicrystalline silicon technologies. Sol. Energy Mater. Sol. Cells 2018, 174, 157-162. [CrossRef]

50. Palanov, N. Life-Cycle Assessment of Photovaltaic Systems; Lund University: Lund, Sweden, 2014.

51. Yu, M.; Halog, A. Solar Photovoltaic Development in Australia-A Life Cycle Sustainability Assessment Study. Sustainability 2015, 7, 1213-1247. [CrossRef]

52. Wu, P.; Ma, X.; Ji, J.; Ma, Y. Review on life cycle assessment of energy payback of solar photovoltaic systems and a case study. Energy Procedia 2017, 105, 68-74. [CrossRef]

53. Ito, M.; Kato, K.; Komoto, K.; Kichimi, T.; Kurokawa, K. A comparative study on cost and life-cycle analysis for $100 \mathrm{MW}$ very large-scale PV (VLS-PV) systems in deserts using $\mathrm{m}-\mathrm{Si}$, a-Si, CdTe, and CIS modules. Prog. Photovolt. Res. Appl. 2008, 16, 17-30. [CrossRef]

54. Zhong, Z.-W.; Song, B.; Loh, P.E. LCAs of a polycrystalline photovoltaic module and a wind turbine. Renew. Energy 2011, 36, 2227-2237. [CrossRef]

55. Mason, J.; Fthenakis, V.M.; Hansen, T.; Kim, H.C. Energy Pay-Back and Life Cycle $\mathrm{CO}_{2}$ Emissions of the BOS in an Optimized 3.5 MW PV Installation. Prog. Photovolt. Res. Appl. 2006, 14, 179-190. [CrossRef]

56. Institute of Environmental Sciences. CML, 2016 CML-IA Characterisation Factors; Leiden University: Leiden, The Netherlands, 2016.

57. ISO. ISO 14040:2006-Environmental Management-Life Cycle Assessment-Principles and Framework; International Organization for Standardization: Geneva, Switzerland, 2006.

58. ISO. ISO 14044:2006-Environmental Management-Life Cycle Assessment-Requirements and Guidelines; International Organization for Standardization: Geneva, Switzerland, 2006.

59. Frischknecht, R.; Heath, G.; Raugei, M.; Sinha, P.; de Wild-Scholten, M. Methodology Guidelines on Life Cycle Assessment of Photovoltaic Electricity, 3rd ed.; Brookhaven National Laboratory: New York, NY, USA, 2016.

60. Lee, D. Fundamentals of Life-Cycle Cost Analysis. Transp. Res. Rec. J. Transp. Res. Board 2002, 1812, $203-210$. [CrossRef]

61. Denholm, P.; Margolis, R. Land-Use Requirements and the Per-Capita Solar Footprint for Photovoltaic Generation in the United States. Energy Policy 2008, 36, 3531-3543. [CrossRef]

62. Ministry of Development, Regional Development Administration for Konya Plain Project. KOP Bölgesinde Arazi ve Enerji Üretimi Planlamasl; Regional Development Administration for Konya Plain Project: Konya, Turkey, 2012. 
63. Bores Bozcaada Santrali. Available online: http://www.demirer.com.tr/santral/bores/index.html (accessed on 13 July 2019).

64. Jordan, D.C.; Kurtz, S.R. Photovoltaic Degradation Rates-An Analytical Review; NREL: Golden, CO, USA, 2012; Volume 5200, p. 18.

65. Ito, M. Life Cycle Assessment of PV systems. In Crystalline Silicon-Properties and Uses; Basu, S., Ed.; IntechOpen: London, UK, 2011.

66. Karadogan, O.; Kilicarslan, T.; ve Celiktas, M.S. The Actual Performance Value of Photovoltaic Solar System In Turkey and Compare with Software Result; SOLARTR: İzmir, Turkey, 2014.

67. Erik, A.; Fraile, D.; Frischknecht, R.; Fthenakis, V.; Held, M.; Kim, H.C.; Pölz, W.; Raugei, M.; de Wild Scholten, M. Methodology Guidelines on Life Cycle Assessment of Photovoltaic Electricity; International Energy Agency, Photovoltaic Power Systems Programme, Rolf Frischknecht, ESU-services Ltd.: Uster, Switzerland, 2009.

68. Jungbluth, N.; Stucki, M.; Frischknecht, R.; Büsser, S. Photovoltaics; ESU-services Ltd. \& Swiss Centre for Life Cycle Inventories: Uster, Switzerland, 2010.

69. Appleyard, D. Light Cycle: Recycling PV Materials. Renew. Energy World Mag. 2009, 109, $28-35$.

70. Abu-Rumman, A.K.; Muslih, I.; Barghash, M.A. Life Cycle Costing of PV Generation System. J. Appl. Res. Ind. Eng. 2017, 4, 252-258.

71. Batman, A.; Bagriyanik, F.G.; Aygen, Z.E.; Gul, O.; Bagriyanik, M. A feasibility study of grid-connected photovoltaic systems in Istanbul, Turkey. Renew. Sustain. Energy Rev. 2012, 16, 5678-5686. [CrossRef]

72. Inflation Calculator. Available online: http://www3.tcmb.gov.tr/inflationcalc2/inflationcalc.php (accessed on 13 July 2019).

73. BP Türkiye-Ürünler ve Servisler-Akaryakıt-Akaryakıt Pompa Satış Fiyatları. Available online: http: //www.bppompafiyatlari.com/ (accessed on 13 July 2019).

74. Kerosen-Kerosen Manufacturers, Suppliers and Exporters on Alibaba.comJetFuel. Available online: https: //www.alibaba.com/trade/search?fsb=y\&IndexArea=product_en\&CatId=\&SearchText=kerosen (accessed on 13 July 2019).

75. Turkish Wind Energy Association. Turkish Wind Energy Statistic Report; Turkish Wind Energy Association: Ankara, Turkey, 2018.

76. Lee, Y.; Tzeng, Y.; Su, C. Life Cycle Assessment of Wind Power Utilization in Taiwan. In Proceedings of the 7th International Conference on Eco Balance, Tsukuba, Japan, 14-16 November 2006.

77. Razdan, P.; Garrett, P. Life Cycle Assessment of Electricity Production from an onshore V110-2.0 MW Wind Plant; Vestas Wind Systems A/S, Hedeager 42, Aarhus N, 8200, Denmark, 2015. Available online: https://www.vestas.com/ \{\}/media/vestas/about/sustainability/pdfs/lcav11020mw181215.pdf (accessed on 13 July 2019).

78. Enercon E-40/6.44-600,00 kW-Wind Turbine. Available online: https://en.wind-turbine-models.com/turbines/ 68-enercon-e-40-6.44 (accessed on 13 July 2019).

79. Ghenai, C. Life Cycle Analysis of Wind Turbine. In Sustainable Development-Energy, Engineering and Technologies-Manufacturing and Environment; Ghenai, C., Ed.; InTech: Melbourne, FL, USA, 2012; p. 27.

80. Chan, D.; Mo, J. Life cycle reliability and maintenance analyses of wind turbines. Energy Procedia 2017, 110, 328-333. [CrossRef]

81. Andersen, P.D.; Bonou, A.; Beauson, J.; Brøndsted, P. Recycling of Wind Turbines; Technical University of Denmark (DTU): Lyngby, Denmark, 2014.

82. Abu-Rumman, A.K.; Muslih, I.; Barghash, M.A. Life Cycle Costing of Wind Genaration System. J. Appl. Res. Ind. Eng. 2017, 4, 185-191.

83. Erdem, O. Bozcaada'da CFD Programı Kullanarak Bir Rüzgar Enerji Santralinin Potansiyelinin Belirlenmesi. Tesisat Mühendisliği 2015, 147, 20-26.

84. Erdem, O.; Batur, B.; Bilge, Z.D.; Temir, G. Bozcaada'da Kurulacak Olan Bir Rüzgar Enerjisi Santralinin Ekonomik Analizi. Tesisat Mühendisliği 2015, 148, 22-27.

85. Ozerdem, B.; Ozer, S.; Tosun, M. Feasibility study of wind farms: A case study for Izmir, Turkey. J. Wind Eng. Ind. Aerodyn. 2006, 94, 725-743. [CrossRef]

86. OECD. Producer Price Indices (PPI). 2019. Available online: https://data.oecd.org/price/producer-priceindices-ppi.htm\#indicator-chart (accessed on 2 May 2019). 
87. Henderson, G. Potential for Reducing Cost of Energy by Scaling Up a Low-Mass wind turbine design. In Proceedings of the 16th International Workshop on Large-Scale Integration of Wind Power, Berlin, Germany, 25-27 October 2017.

88. Fathiyah, R.; Mellott, R.; Panagoda, M.; Lane, M. Windmill Design Optimization through Component Costing; IEEE Seminar: London, UK, 2000.

89. Merta, G.; Linkeb, B.; Auricha, J. Analysing the Cumulative Energy Demand of Product-Service Systems for wind turbines. Procedia CIRP 2017, 59, 214-219. [CrossRef]

90. Gkantou, M.; ve Baniotopoulos, C.C. Life Cycle Analysis of Onshore Wind Turbine Towers. In Proceedings of the 2nd International TU1304 WINERCOST, Catanzaro, Italy, 21-23 March 2018.

91. Kim, T.H.; Chae, C.U. Environmental Impact Analysis of Acidification and Eutrophication Due to Emissions from the Production of Concrete. Sustainability 2016, 8, 1. [CrossRef]

(C) 2019 by the authors. Licensee MDPI, Basel, Switzerland. This article is an open access article distributed under the terms and conditions of the Creative Commons Attribution (CC BY) license (http://creativecommons.org/licenses/by/4.0/). 